Article

\title{
Berry Quality of Grapevine under Water Stress as Affected by Rootstock-Scion Interactions through Gene Expression Regulation
}

\author{
Alessandra Zombardo ${ }^{1,2, * \mathbb{C}}$, Erica Mica ${ }^{3}$, Sergio Puccioni ${ }^{1}{ }^{1}$, Rita Perria ${ }^{1}$, Paolo Valentini ${ }^{1}$, \\ Giovan Battista Mattii ${ }^{2}$ (D) Luigi Cattivelli $^{3}(\mathbb{D})$ and Paolo Storchi ${ }^{1}(\mathbb{D}$ \\ 1 Council for Agricultural Research and Economics, Research Centre for Viticulture and Enology, \\ Viale Santa Margherita, 80, 52100 Arezzo, Italy; sergio.puccioni@crea.gov.it (S.P.); \\ rita.perria@crea.gov.it (R.P.); paolo.valentini@crea.gov.it (P.V.); paolo.storchi@crea.gov.it (P.S.) \\ 2 Department of Agriculture, Food, Environment and Forestry (DAGRI), University of Florence, \\ Piazzale delle Cascine 18, 50144 Florence, Italy; giovanbattista.mattii@unifi.it \\ 3 Council for Agricultural Research and Economics, Research Centre for Genomics and Bioinformatics, \\ Via San Protaso 302, 29017 Fiorenzuola d'Arda (PC), Italy; erica.mica@crea.gov.it (E.M.); \\ luigi.cattivelli@crea.gov.it (L.C.) \\ * Correspondence: alessandra.zombardo@crea.gov.it; Tel.: +39-0575-353021
}

Received: 30 March 2020; Accepted: 6 May 2020; Published: 12 May 2020

\begin{abstract}
Despite phenotypic plasticity that allows the adaptation to harsh environments, when vines experience severe abiotic stresses, they can suffer from metabolic damages affecting grape production and quality. Grafting is an affordable strategy to mitigate these negative consequences since the rootstock can increase the drought tolerance in the scion. This work explored the effects of pre-veraison water deficit on vines grafted on different rootstocks (Mgt 101-14 and 1103 Paulsen) to obtain physiological, biochemical, and molecular information about the influence on grape quality. Repeated measurements were carried out to assess vine physiology, production, technological maturity, and berry phenolic composition. qRT-PCRs were executed on berry skins at maturity to assess the expression levels of ten genes and five miRNAs involved in the phenylpropanoid pathway. Water stress caused significant alterations in grape technological maturity. The rootstock effect was not detected in primary metabolism while it was well defined in the accumulation of phenolic compounds in berries (such as anthocyanins). Finally, significant differences were identified in gene and miRNA expression between water-stressed and well-watered vines. In conclusion, the response to water stress can be modulated by rootstocks, which mainly act by regulating secondary metabolism, especially in grapes.
\end{abstract}

Keywords: Vitis vinifera; rootstock; water stress; berry ripening; secondary metabolism; gene expression; miRNA

\section{Introduction}

The burden of climate change is a major concern among winemakers because the grapevine, despite its ability to adapt to environmental adversities, is one of the fruit crops most sensitive to severe drought conditions and water shortage [1-3]. According to reliable forecasts, climate change is expected to cause a steady global increase of air temperature (with warming up to $1.5^{\circ} \mathrm{C}$ between 2030 and 2052) and a strong modification in the precipitation pattern [4]. In viticulture, the presence of moderate stress is desirable to guarantee higher quality in the chemical composition of red grapes and confer positive organoleptic characteristics to the wines produced [5-7]. Nevertheless, if the environment becomes excessively limiting due to the combined effect of drought, high air temperature, 
and high evaporative demand during summer, the vines can suffer from serious damage, and grape yield and berry quality can be strongly affected [8-10].

The recommended adaptive strategies for tackling climate changes in viticulture include the exploitation of some rootstocks able to confer to the scion a higher drought and water deficit tolerance [11,12]. Since grafting introduction in Europe at the end of the 19th century as the only effective solution to overcome phylloxera (Daktulosphaira vitifoliae Fitch), only a few genotypes (as Vitis species or interspecific hybrids) are commonly used as rootstocks worldwide [13]. The rootstocks selection also offers the possibility to confer further positive traits to the scion, modifying its vigor and phenology, but most of all increasing the tolerance to environmental stresses $[14,15]$. The rootstocks act as an interface between the soil and the aerial portion of the plant [16], but the knowledge on the molecular networks regulating the rootstock-scion interaction mechanisms is still limited, particularly it is interesting to shed light on those pathways influencing grape quality under abiotic stress conditions [17]. It is known that the rootstock can alter gene expression in the scion, especially in the presence of stress, diseases, or limiting factors [18,19]. In grapes, the major changes at the transcriptomic level concern several structural genes and transcription factors belonging to the phenylpropanoid pathway, responsible for flavonoid and stilbene biosyntheses [20]. Flavonoids and stilbenes are two different classes of phenolic compounds that accumulate in berries, mainly in skin tissues, during the ripening phases. As secondary metabolites, they have multiple biological functions, protecting leaves and fruits against UV photo-oxidative damage, acting as free radical scavengers, and playing a role against biotic and abiotic stresses [21,22]. The accumulation of secondary metabolites in grapes plays a fundamental role, because higher quantities of phenolics are desirable and positively related to oenological quality, as they affect the main organoleptic characteristics of wines (i.e., color, flavor, texture, and astringency) and improve their aptitude for ageing [23]. This research aimed to study the effects of two rootstocks with opposite characteristics on the grapes produced by vines that have undergone pre-veraison water stress. The activity was set up in an experimental system of potted adult Pinot noir grapevines, which included vines grafted on 1103 Paulsen (drought-tolerant (P)) and Mgt 101-14 (drought-sensitive (M)), and not grafted vines (NGC). During the 2018 growing season, the pot system was used to test the rootstock-effect applying three different irrigation protocols (severe water deficit (WS-S), intermediate water deficit (WS-I), and well-watered control (WW)) on plant physiology and grape quality. Moreover, the expression of ten genes and five miRNA involved in the phenylpropanoid pathway or stress response was tested in berry skins at maturity. For this purpose, we chose specific genes and miRNAs that we already described as differentially expressed among the three root systems, in previous work on the same vines, but in conditions of equal water supply [24], to check any expression differences still persistent in the grapes at maturity due to an early prolonged water limitation during berry development.

\section{Materials and Methods}

\subsection{Plant Materials}

A pot system for grapevines monitoring was set at CREA-VE (Research Centre for Viticulture and Enology), in Arezzo ( $43^{\circ} 28^{\prime} 36^{\prime \prime} \mathrm{N}, 11^{\circ} 49^{\prime} 27^{\prime \prime} \mathrm{E}$, Italy). It consisted of $70 \mathrm{~L}$ plastic pots, filled with a silty-clay texture soil ( $40 \%$ clay, $41 \%$ silt, and $19 \%$ sand), with a volumetric soil water content of $34 \%$ at field capacity, collected from a real vineyard of the Chianti Classico D.O.C.G. district in Tuscany, Italy [25]. The research was made with 12-year-old Pinot noir potted vines, clone ENTAV 115 grafted onto two different rootstocks: 1103 Paulsen (P) V. berlandieri $x$ V. rupestris, highly vigorous and known for its drought tolerance, and Mgt 101-14 (M) V. riparia $\times$ V. rupestris, less vigorous and less tolerant to drought [26]; not grafted vines were used as reference (not grafted control (NGC)). The vines were trained on upward vertical shoot positioned trellis, with spur cordon pruning and an average of 10 buds per vine. The pots were positioned in an outdoor area, subdivided into 3 rows spaced at the distance of $1 \mathrm{~m}$ within the row and $2.5 \mathrm{~m}$ between the rows, with orientation north to 
south and were arranged in a complete randomization scheme with 9 replicates for each root system. The vines were maintained in the same agronomic conditions: all the pots were fertilized before the beginning of the vegetative season with $40 \mathrm{~g}$ of Nitrophoska (12N-12P-17K, Eurochem Agro, Cesano Maderno, MB, Italy), and pest management was scheduled with calendar sprays at 10-day intervals. Irrigation was abundantly supplied (at field capacity) to each pot by automated drip emitters from the end of May to harvest (at 3-days intervals, a timeframe considered commensurate to maintain the water status of the plants in non-limiting conditions [27]), except for the water stress trial period in which three different irrigation protocols were applied (see below), each one on a row of 9 pots.

\subsection{Weather Conditions and Phenological Surveys}

The climate data were recorded during the 2018 vegetative season using a non-stop automated control unit (Ecotech $\mathrm{GmbH}$, Bonn, Germany) placed nearby the experimental pot system area. The following parameters in the period between April 1st and October 31st (conventionally considered the vegetative period for the grapevine) were measured: daily maximum temperature $\left(\mathrm{T} \max ,{ }^{\circ} \mathrm{C}\right)$, daily average temperature $\left(\mathrm{T} \mathrm{avg},{ }^{\circ} \mathrm{C}\right)$, daily minimum temperature $\left(\mathrm{T} \mathrm{min},{ }^{\circ} \mathrm{C}\right)$, and daily rainfall $(\mathrm{mm})$. The data collected were daily checked and processed at the end of the vegetative season. Growing degree days (GDDs) and the Winkler Index were calculated on a $10{ }^{\circ} \mathrm{C}$-based temperature, according to Winkler [28], to get information about the sum of all the daily average temperatures that influenced plant growth and grape maturation.

During the growing season, specific surveys were carried out to observe the main phenological phases of grapevine (date of budburst, flowering, veraison, and maturity) [29].

\subsection{Irrigation Protocols}

During the 2018 vegetative season, a water stress trial was set on the experimental pot system to get information on the behavior of the three root systems (M, P, and NGC) in case of different water availability. The water stress trial was designedly held during berry growth Phase I [30], from cluster closure (BBCH 79) to veraison (BBCH 83) [29]. It started on July 4th (Day of Year (DOY) 185) and ended on July 29th (DOY 210), when the vines reached full veraison. Following a protocol previously tested at CREA-VE [31], three irrigation strategies were applied, using a calculated standard water supply apiece. The trial was split into two levels of water stress, a severe deficit (WS-S; $25 \%$ of field capacity) and an intermediate deficit (WS-I; $40 \%$ of field capacity), which provided for manual water supplies every three days, plus a control level (WW; $90 \%$ of field capacity) with drip irrigation every three days. The water stress level in the vines was monitored by midday stem water potential $\left(\Psi_{\text {stem }}\right.$, see below), usually before the last rewatering of the week [32]. During the execution of the water stress trial, the pot surfaces were coated with aluminum foils to oppose soil water evaporation and avoid possible rainfall infiltrations.

\subsection{Measurements on Grapevine Physiology}

Midday stem water potential, leaf gas exchanges, and chlorophyll fluorescence were measured before (DOY 184), during (DOYs 194 and 208), and after the water stress trial (DOYs 221 and 232, the latter point except for chlorophyll fluorescence) to evaluate the starting physiological conditions of the vines, to confirm the onset of water stress, verify the water status and the photosynthetic efficiency of each root system combination, and check if the recovery after water deprivation occurred. The measurements per vine were carried out on three fully developed intact leaves grown between the 4th and 10th node from the shoot base, chosen on the same side of the canopy, for a total of nine replicates for each root system and water protocol; the same leaves were used to determine all the parameters in each measurement point. The midday stem water potential ( $\left.\Psi_{\text {stem }}\right)$ was assessed with a pressure chamber (Model 670, PMS Instruments Co., Albany, OR, USA), according to Scholander [33]. In particular, $\Psi_{\text {stem }}$ measurements were always taken between 12:00 and 13:00, after enclosing each 
leaf in a plastic bag surrounded by an aluminum foil (for at list $60 \mathrm{~min}$ ), to stop transpiration and enable the leaf to equilibrate with the water potential of the stem.

Leaf gas exchanges were detected as net photosynthesis (A), transpiration rate (E), and stomatal conductance ( $g s)$ using an infrared gas analyzer (Ciras 1-PP Systems, Amesbury, MA, USA) equipped with a leaf chamber; $\mathrm{CO}_{2}$ flow was set at $400 \mathrm{ppm}$, relative humidity to ambient level, and saturating light at $1200 \mu \mathrm{mol} \mathrm{m}^{-2} \mathrm{~s}^{-1}$. The measurements were always recorded in the morning, between 10:00 and 12:00.

Chlorophyll fluorescence was assessed using a Handy Peas chlorophyll fluorometer (Hansatech Instruments, Norfolk, UK) on dark-adapted leaves. The leaf area to be analyzed was covered with a proper plastic clip for at least $30 \mathrm{~min}$. Then, once the instrument handpiece connected and the clip tab opened, the leaf tissue was exposed to a saturating light pulse (duration, $1 \mathrm{~s}$; intensity, $3000 \mu \mathrm{mol} \mathrm{m}{ }^{-2} \mathrm{~s}^{-1}$; and wavelength, $650 \mathrm{~nm}$ ) and the output data were collected. The maximum efficiency (quantum yield) of photosystem II was automatically calculated by the device as Fv/Fm ratio according to Kitajima and Butler [34]. Here too, the measurements were executed in the last hours of the morning, between 11:00 and 12:00.

\subsection{Grape Production, Berry Characteristics and Pruning Wood Weight}

At the harvest (carried out on August 20th—DOY 232), the grapes were manually hand-picked. The main production traits were determined: yield per vine $(\mathrm{g})$, clusters per vine (number), cluster weight $(\mathrm{g})$, and berry weight $(\mathrm{g})$. The following berry characteristics were assessed on a pool of 30 berries: berry diameter $(\mathrm{cm})$, skin weight $(\mathrm{g})$, seed weight $(\mathrm{g})$, and seeds per berry (number). During the winter, the 1-year-old pruning wood was weighed $(\mathrm{g})$ with a portable electronic scale.

\subsection{Technological Maturity and Phenolic Compound Contents}

At the harvest (August 20th-DOY 232), 100 berries were randomly selected to assess technological maturity on must, measuring sugars $\left({ }^{\circ} \mathrm{Brix}\right), \mathrm{pH}$, and titratable acidity ( $\mathrm{g} / \mathrm{L}$ tartaric acid), according to O.I.V. official methods [35].

To evaluate phenolic maturity, a pool of 30 berries was randomly selected on the clusters collected from each vine. Total phenolic compounds were assessed in berry skins and seeds, according to the method described by Di Stefano and Cravero [36]. In particular, seeds and skins were manually separated; the extraction of phenolic compounds was carried out with $25 \mathrm{~mL}$ of a tartaric buffer solution $(12 \% v / v$ ethanol-water, added with $2 \mathrm{~g} / \mathrm{L}$ of sodium metabisulfite, $5 \mathrm{~g} / \mathrm{L}$ of tartaric acid, and $\mathrm{NaOH}$ $1 \mathrm{~N} 22 \mathrm{~mL} / \mathrm{L}$ to adjust the $\mathrm{pH}$ to 3.2). After $4 \mathrm{~h}$ of incubation, the samples were ground using an Ultra Turrax T-45 homogenizer (IKA, Staufen im Breisgau, Germany), then were centrifuged, and the pellets were washed and centrifuged again with the buffer solution. The supernatants were joined together in a volumetric flask to reach exactly $50 \mathrm{~mL}$.

Berry skin extracts were properly diluted (dilution $=1: 50$ ) in a water-ethanol-hydrochloric acid solution (70:30:1) and the absorbance of each sample was read at $540 \mathrm{~nm}$ (E540) using a UV-VIS spectrophotometer (8453 - Hewlett-Packard, Palo Alto, CA, USA). Skin anthocyanins (mg/L) were determined with the following equation: $16.17 \times$ E540 $\times$ dilution. The results were then recalculated to express the values as $\mathrm{mg} / \mathrm{kg}$ of grapes. The content of skin polyphenols $(\mathrm{mg} / \mathrm{kg})$ and seed polyphenols $(\mathrm{mg} / \mathrm{kg})$ was assessed as described by Singleton [37].

On berry skins extracts, the contents of phenolic compounds were assessed by HPLC following the method of Gómez-Alonso [38]. The analyses were performed using an 1100 Series HPLC (Agilent, Santa Clara, CA, USA), equipped with a solvent degasser, quaternary pump, and diode array detector and controlled by a PC running Agilent ChemStation for LC 3D System software (Agilent, Santa Clara, CA, USA). A Luna ${ }^{\circledR}$ Omega $5 \mu$ m Polar C18 Column (Phenomenex, Torrance, CA, USA) was employed to separate phenolic compounds. Commercial standards of phenolic compounds (Extrasynthese, Genay, France) were used as a reference to calculate individual retention times and to recognize absorption spectra. In total, the experiment comprised 27 different samples (vines with three different 
root systems-M, P, and NGC; three irrigation protocols-WS-S, WS-I, and WW; and three vines as biological replicates), each consisting of the pool of 30 berries collected.

\subsection{Grape Sampling for Molecular Analyses}

Grape samples for molecular analyses were collected at harvest, on August 20th (DOY 232). The harvest date was set at the time when, according to random berry samplings, the grapes reached a minimum sugar content of $20^{\circ}$ Brix. Berries (15 per vine) were randomly hand-picked at different positions of the clusters, dissected to separate skin tissues, frozen in liquid nitrogen, and stored in Falcon tubes at $-80{ }^{\circ} \mathrm{C}$ for further processing. Only two irrigation protocols were considered for gene expression analyses: the most restrictive WS-S as water stress and WW as control. In total, the experiment entailed 18 different samples (each comprising the skins of 15 berries): vines with three different root systems (Mgt 101-14 (M), 1103 Paulsen (P), and not grafted control (NGC)), two irrigation protocols (severe water stress (WS-S) and well-watered (WW)), and three vines as biological replicates.

\subsection{RNA Extraction and qRT-PCR Analyses}

Total RNA extraction was performed using Plant RNA Isolation Reagent (PRIR, Life Technologies, Carlsbad, CA, USA) starting from $200 \mathrm{mg}$ of ground berries skin tissue in $1 \mathrm{~mL}$ of reagent, followed by RNA Clean up and Concentration kit (NorgenBiotek Corp., Thorold, ON, Canada), according to manufacturers' protocols. Total RNA was then subjected to Dnase I treatment (DNA-freeTM Kit, Applied Biosystems, Foster City, CA, USA). The concentration and purity of total RNAs were evaluated using a Nanodrop 2000 Spectrophotometer (Thermo Fisher Scientific, Waltham, MA, USA) and their integrity was assessed by an Agilent 2100 Bioanalyzer using an RNA 6000 Nano kit (Agilent Technologies, Santa Clara, CA, USA), according to the manufacturer's instructions. All the samples were suitable to obtain meaningful gene expression data, confirmed by consistent RIN outputs (RNA Integrity Number $\geq 7$ ). RNA samples were stored at $-80^{\circ} \mathrm{C}$ for subsequent analyses.

qRT-PCR analyses were performed on ten genes and five miRNAs (Table S1) already tested in related experimental work [24]. cDNA was produced from $200 \mathrm{ng}$ of DNase-treated RNA using the SuperScript II Reverse transcriptase kit (Invitrogen Corp., Carlsbad, CA, USA) according to the manufacturer's instructions. The real-time PCRs were performed in a final volume of $10 \mu \mathrm{L}$, with SsoAdvanced Universal SYBR ${ }^{\circledR}$ Green PCR Supermix (BioRad, Hercules, CA, USA), considering three technical replicates for each sample. The plates were analyzed on a 7300 real-time PCR System (Life Technologies, Carlsbad, CA, USA) with the following conditions: $95{ }^{\circ} \mathrm{C}$ for $30 \mathrm{~s}$, followed by 40 cycles of $95^{\circ} \mathrm{C}$ for $10 \mathrm{~s}$ and $60^{\circ} \mathrm{C}$ for $1 \mathrm{~min}$ plus 1 cycle for primer dissociation. miRNAs expression levels were assessed by stem-loop real-time PCR [39]. The RT reactions were performed starting from 200 ng of DNase treated total RNA, using Superscript III (Invitrogen Corp., Carlsbad, CA, USA), according to the manufacturer's instructions. The real-time PCRs were set up in $25 \mu \mathrm{L}$ using SYBR Green PCR Master Mix (Applied Biosystem, Foster City, CA, USA). The three independent biological replicates were analyzed in triplicate, on a 7300 real-time PCR System (Life Technologies, Carlsbad, CA, USA) with the following conditions: $95^{\circ} \mathrm{C}$ for $10 \mathrm{~min}$, followed by 40 cycles of $95^{\circ} \mathrm{C}$ for $15 \mathrm{~s}$ and $60^{\circ} \mathrm{C}$ for $1 \mathrm{~min}$ plus 1 cycle for dissociation curve. The relative quantification was calculated from average $\mathrm{Ct}$ values, using the Log2 Fold Change (i.e., $-\Delta \Delta \mathrm{Ct}$ method) [40], considering a poly-ubiquitin transcript (VvUBI, VIT_219s0177g00040) as an internal standard [18]. Not grafted vines subjected to the well-watered protocol (NGC-WW) were always used as a control to highlight both the effects due to water stress and root system.

\subsection{Statistical Analyses}

Statistical analyses on the obtained results were done with the software Statgraphics (Statgraphics Technologies Inc., The Plains, Virginia, VA, USA). The data were processed by a two-way analysis of variance (ANOVA) to evaluate the influence of the individual factors "root system" and "water protocol" and their possible interaction. Statistically significant differences were assumed for $P<0.05$. 
The mean values were then separated by the LSD post-hoc test $(P<0.05)$, except for the mean values of anthocyanin profiles of berry skins that were separated by the Bonferroni test $(P<0.05)$, as described in [41]. As for qRT-PCR results, $\triangle \mathrm{Ct}$ data were checked for homoscedasticity with Levene's test that confirmed the homogeneity of variance. Data were then processed by a one-way ANOVA, and statistically significant differences were assumed for $P<0.05$. Finally, the mean values were separated by the LSD test $(P<0.05)$.

\section{Results}

\subsection{Weather Conditions and Phenological Surveys}

The climate data recorded in the experimental area are reported in Figure 1. In general, 2018 was a warm season (compared to the historical data of the climate region of Arezzo found at: www.sir.toscana.it), with 1457 GDDs accumulated in the period April 1st-August 20th (harvest date). The sum of GDDs was very similar to the same time frame in 2012 (1450 GDDs), the year when a transcriptomics pilot project was carried out on the same experimental pot system [24]. During the water stress trial, the averaged temperature values recorded were the following: $\mathrm{T} \max =32.8{ }^{\circ} \mathrm{C}$; $\mathrm{T}$ avg $=24.1^{\circ} \mathrm{C}$; and $\mathrm{T} \min =15.2^{\circ} \mathrm{C}$. The maximum daily temperature breached $35^{\circ} \mathrm{C}$ on four days, with the highest temperature recorded $\left(35.7^{\circ} \mathrm{C}\right)$ on July 14 th (DOY 195). Few rain events were recorded with a limited amount of rainfall, for a total of $1.6 \mathrm{~mm}$. The GDDs accumulated during the water stress trial were 367. Considering, on the other side, the period from full veraison to harvest (from July 30th (DOY 211) to August 20th (DOY 232)), the averaged temperature values recorded were the following: $\mathrm{T} \max =34.4^{\circ} \mathrm{C}$; $\mathrm{T}$ avg $=25.1^{\circ} \mathrm{C}$; and $\mathrm{T} \min =16.7^{\circ} \mathrm{C}$ ). The maximum daily temperature breached $35^{\circ} \mathrm{C}$ on ten days, with the highest temperature recorded $\left(37.7^{\circ} \mathrm{C}\right.$, the highest of the whole vegetative season) on August 7th (DOY 219). The amount of rainfall was very scarce, with only $0.4 \mathrm{~mm}$. The GDDs accumulated in this time frame were 319.

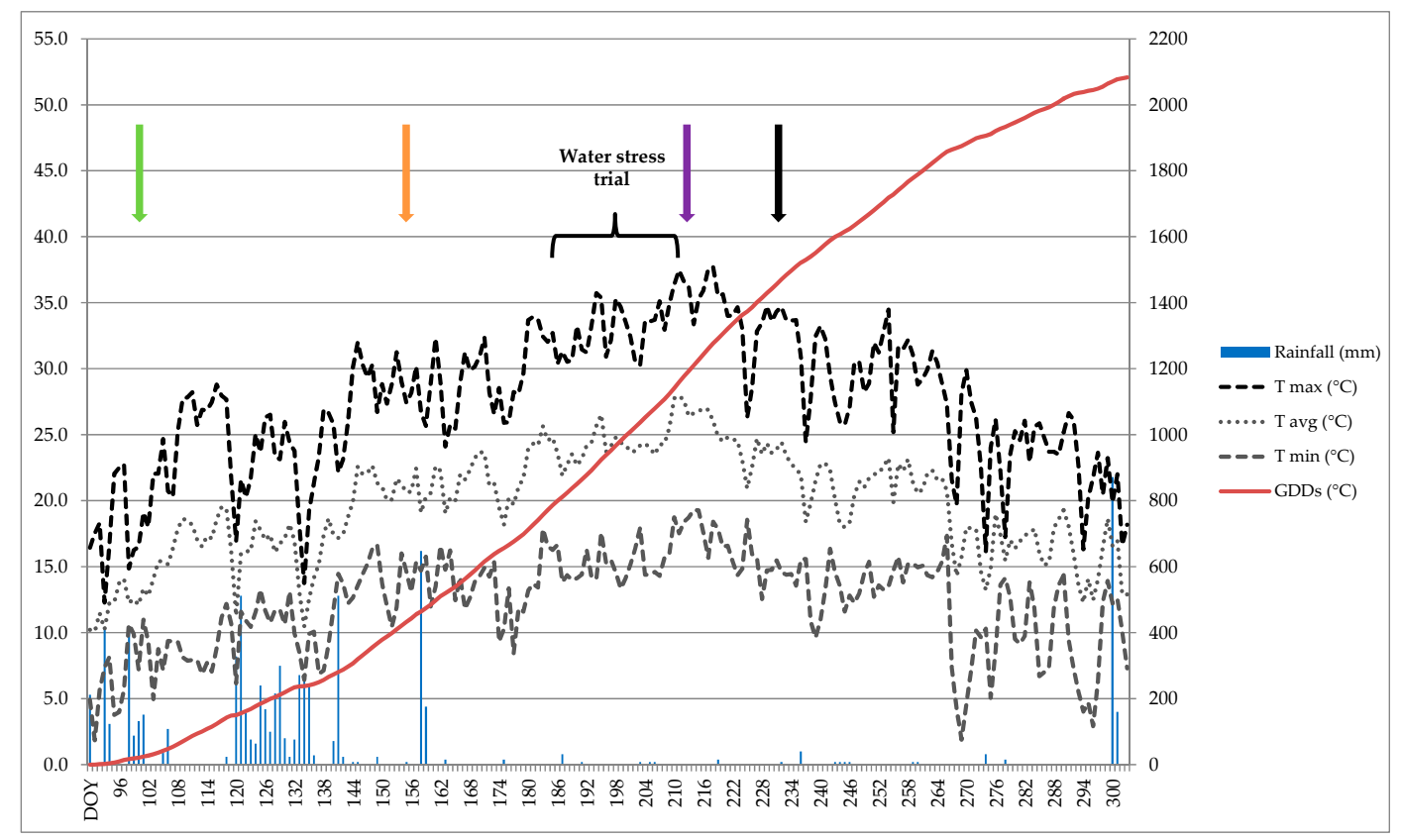

Figure 1. Weather conditions (April 1st-October 31st) of the 2018 vegetative season. Rainfall, daily rainfall (mm); $\mathrm{T}$ max, daily maximum temperature $\left({ }^{\circ} \mathrm{C}\right) ; \mathrm{T}$ avg, daily average temperature $\left({ }^{\circ} \mathrm{C}\right) ; \mathrm{T} \min$, daily minimum temperature $\left({ }^{\circ} \mathrm{C}\right)$; GDDs, growing degree days (base $10^{\circ} \mathrm{C}$ ); DOY, day of year. The green arrow indicates the date of bud burst (DOY 100), the orange arrow indicates the date of flowering (DOY 155), the purple arrow indicates the date of full veraison (DOY 211), and the black arrow indicates the date of harvest (DOY 232). The black brace indicates the period of water stress trial (July 4th (DOY 185) to July 29th (DOY 210)). 
The colored arrows in Figure 1 indicate the different phenological phases of grapevine (budburst, flowering, full veraison, and harvest) that, according to our surveys, took place synchronously for all the root systems considered.

\subsection{Measurements on Grapevine Physiology}

The measurement of midday stem water potential $\left(\Psi_{\text {stem }}\right)$, leaf gas exchanges $(g s, \mathrm{~A}$, and $\mathrm{E})$, and chlorophyll fluorescence (Fv/Fm) executed before (DOY 184), during (DOYs 194 and 208), and after (DOYs 221 and 232, the latter except for chlorophyll fluorescence) the induced water stress confirmed water status alterations and a decrease in the photosynthetic performance in the vines subjected to both WS-S and WS-I irrigation protocols, while the vines with optimal irrigation (WW) had more uniform values and maintained their physiological leaf functionality.

$\Psi_{\text {stem }}$ measurements (Figure 2 and Table S2) were similar among the vines before the application of the differentiated irrigation protocols; during the water stress trial, $\Psi_{\text {stem }}$ reached much lower values in the vines subjected to water limitation, especially at DOY 208, with significant differences among the two reduced irrigation protocols (WS-S and WS-I), as well as compared to well-watered vines (WW). This result demonstrates that the two different amounts of water supplied induced two significantly different levels of water stress, as required by the experimental plan. Once irrigation to field capacity was resumed, the water status returned to similar among the vines, with more negative values compared to the date before the water stress trial (Figure 2A), probably due to leaf ageing [42] and the restrictive climatic conditions of mid-August. In fact, between veraison and harvest, the daily maximum temperatures often exceeded $35^{\circ} \mathrm{C}$ (Figure 1). No significant differences were detected in vine water status among the three different root systems (M, P, and NGC), at none of the measurement points. Therefore, the rootstock did not have any influence on the $\Psi_{\text {stem }}$ parameter (Figure 2B and Table S2).

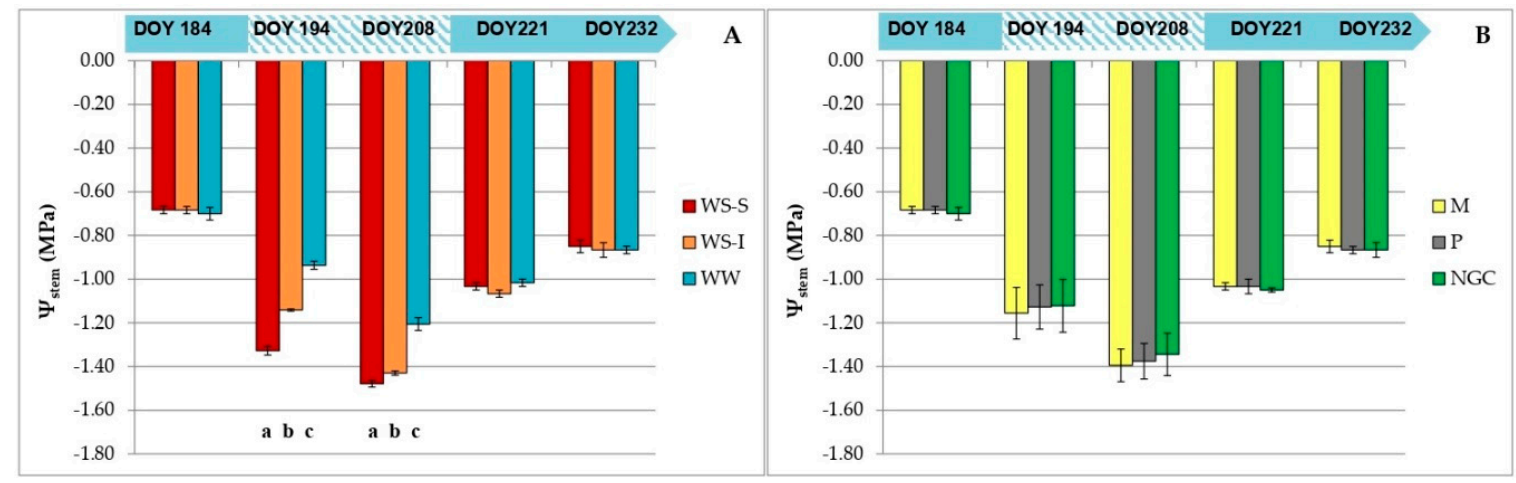

Figure 2. Midday stem water potentials ( $\left.\Psi_{\text {stem }}, \mathrm{MPa}\right)$ in adult leaves of Pinot noir, subjected to three irrigations protocols: (A) WS-S in red, WS-I in orange, and WW in blue. Leaf Water Potentials ( $\Psi_{\text {stem, }}$ $\mathrm{MPa}$ ) in adult leaves in the three root systems: (B) Mgt 101-14 (M) in yellow, 1103 Paulsen (P) in dark grey, and not grafted vines (NGC) in green. The measurements were conducted before (DOY 184), during (DOYs 194 and 208, marked with dashed lines), and after (DOYs 221 and 232) the water stress trial. The bars indicate the standard error. Different letters indicate significant differences (LSD test, $P<0.05)$.

Regarding leaf gas exchanges (Figure 3 and Tables S3-S5), all vines had similar trends before starting the water stress trial, but during the water deficit, the vines with limited water supply suffered a sharp drop in stomatal conductance (gs), net photosynthesis (A), and transpiration (E). Once abundant water was restored, WS-S and WS-I vines resumed their functionality, albeit in some cases at a lower level than pre-stress conditions (Figure 3A-C). From the values recorded at DOY 208, there was a significant drop in gas exchanges in all the vines, and a less optimal physiological condition was evident even in well-watered vines (as can also be seen from $\Psi_{\text {stem }}$ ). Given that these measurements 
were made at the maximum distance from the previous irrigation, these results can be explained by the fact that in the days before the surveys the temperatures were particularly limiting (T max over $35^{\circ} \mathrm{C}$ and $\mathrm{T}$ min over $24^{\circ} \mathrm{C}$ ), and thermal or radiative stress due to a heatwave may have arisen [43,44]. However, despite the low values of the physiological parameters ( $\Psi_{\text {stem }}, g s, \mathrm{~A}$, and E) in WW vines, significant differences persisted in comparison to the vines subjected to WS-S and WS-I irrigation protocols (Figure $3 \mathrm{~A}-\mathrm{C}$ ).
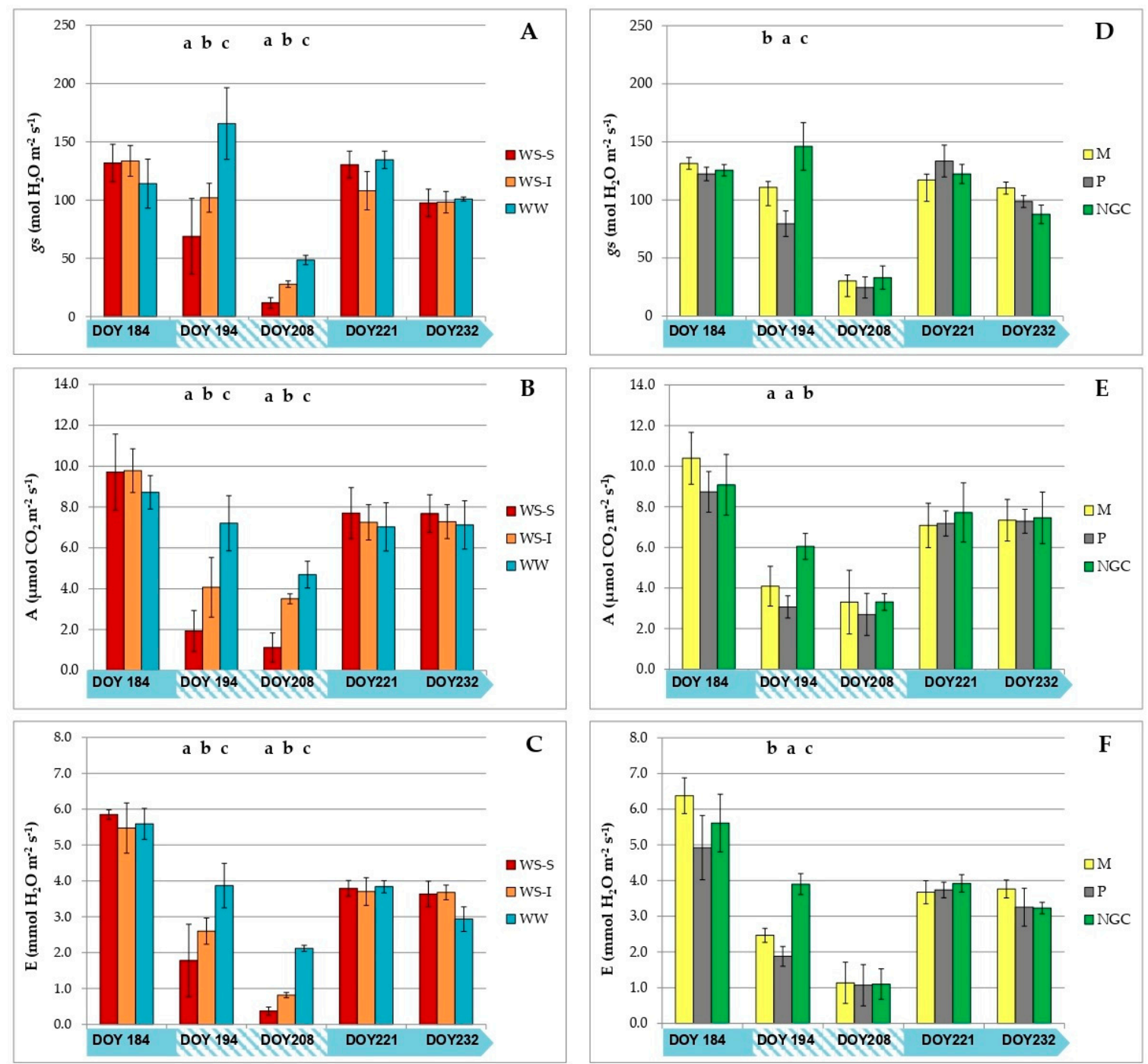

Figure 3. Leaf gas exchange: (A-C) Stomatal conductance $(g s)$, net assimilation (A), and leaf transpiration (E) in adult leaves of Pinot noir, subjected to three irrigations protocols (WS-S in red, WS-I in orange, and WW in blue); and (D-F) stomatal conductance ( $g s)$, net assimilation (A), and leaf transpiration (E) in adult leaves of Pinot noir grafted on Mgt 101-14 (M, in yellow), 1103 Paulsen ( $\mathrm{P}$, in dark grey), and not grafted vines (NGC, in green). The measurements were conducted before (DOY 184), during (DOYs 194 and 208, marked with dashed lines), and after (DOYs 221 and 232) the water stress trial. The bars indicate the standard error. Different letters indicate significant differences (LSD test, $P<0.05)$.

The rootstocks had a statistically significant effect on gas exchanges only at the second measurement point, the first included in the water stress trial, namely at DOY 194. In general, not grafted vines (NGC) showed better performances. Under optimal irrigation conditions, no significant differences emerged between grafted and not grafted vines (Figure 3D-F). 
Chlorophyll fluorescence (Figure 4 and Table S6) measurements were performed on the same leaves and the same days as the other physiological parameters. At the starting conditions (DOY 184), the Fv/Fm parameter was statistically identical for all the vines. During the water stress trial, this value was significantly lower in the measurements performed on the vines with reduced water supply. Once the irrigation was restored, $\mathrm{Fv} / \mathrm{Fm}$ returned similar among the vines, and also similar to pre-treatment values (Figure $4 \mathrm{~A}$ ). About the root system, it did not determine any difference in chlorophyll fluorescence throughout the investigation period (Figure 4B).

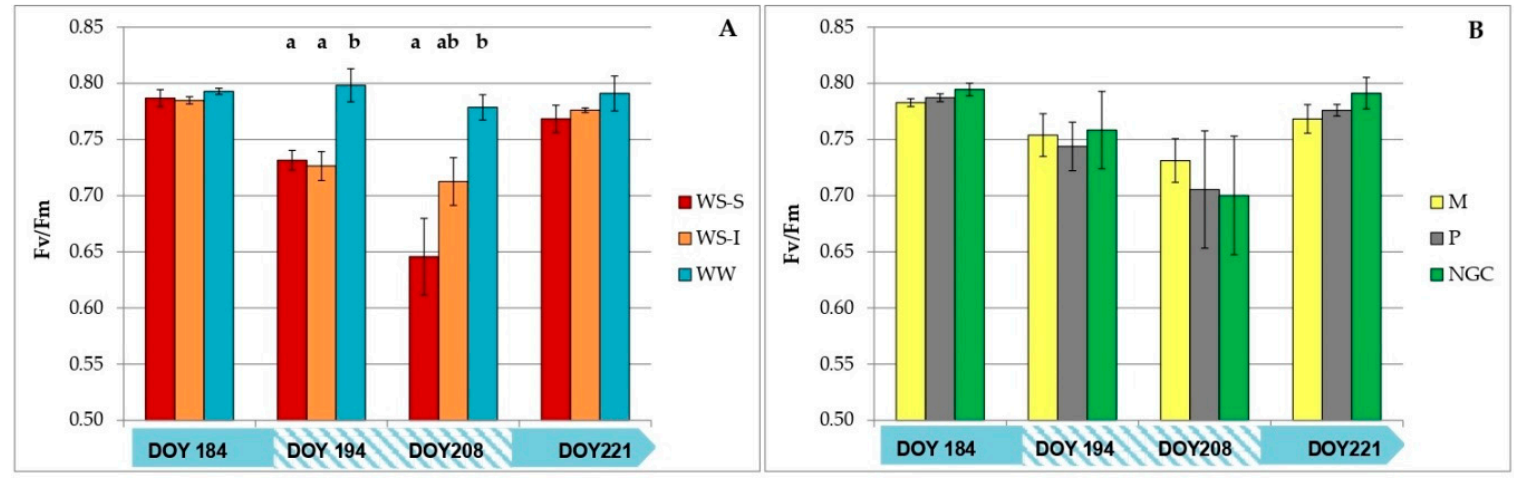

Figure 4. Chlorophyll fluorescence (Fv/Fm) in adult leaves of Pinot noir, subjected to three irrigations protocols: (A) WS-S in red, WS-I in orange, and WW in blue. Chlorophyll fluorescence (Fv/Fm) in adult leaves in the three root systems: (B) Mgt 101-14 (M) in yellow, 1103 Paulsen (P) in dark grey, and not grafted vines (NGC) in green. The measurements were conducted before (DOY 184), during (DOYs 194 and 208, marked with dashed lines), and after (DOY 221) the water stress trial. The bars indicate the standard error. Different letters indicate significant differences (LSD test, $P<0.05$ ).

According to the statistical analyses carried out on the results of all the measurements on grapevine physiology, the interaction of root system $\times$ water protocol did not have a statistically significant effect, confirming that the differences that emerged were caused by the individual factors (as reported in Tables S2-S6).

\subsection{Grape Production, Berry Characteristics and Pruning Wood Weight}

At harvest, all clusters had a similar shape, typical of Pinot noir variety: small, compact, and cylindrical. The berries had a medium length and width, spheroidal shape, and homogeneous black skin. None of the production parameters (yield per vine, clusters per vine, and cluster weight) were influenced by the root system or water protocol (Table 1). Yield per vine was generally low, and although alterations caused by different irrigation protocols were expected [45], grape production was similar most likely due to the limitations given by pot-growth conditions, a result that is supported by those obtained by other authors previously [46-48].

No differences emerged in berry weight or berry diameter. On the contrary, water stress led to some differences in skin weights. In particular, WW vines had lighter berry skins, than ones under severe water stress (WS-S). The root system factor caused some differences at the seed level. NGC vines had a significantly higher number of seeds per berry, but the weight of the individual seeds was lower, especially compared to $\mathrm{P}$ vines. Conversely, the water protocols did not affect seed characteristics (Table 1).

Finally, significant differences emerged in the pruning wood weight, due to both the rootstock, and the irrigation protocol. As expected and well-known in viticulture, the highest pruning wood weight was assessed in P vines, a rootstock that can confer to the scion high vegetative vigor, while NGC vines had less than half of wood biomass. Significantly lower values were also detected in water-stressed vines (both WS-S and WS-I, which had a similar pruning wood weight) compared to well-watered vines (Table 1). 
According to the statistical analyses carried out, the interaction of root system $\times$ water protocol did not have a statistically significant effect, confirming that the differences that emerged were caused by the individual factors.

Table 1. Production parameters, berry characteristics, and pruning wood weight of Pinot noir vines grafted on Mgt 101-14 (M), 1103 Paulsen (P), and not grafted vines (NGC), treated with three irrigations protocols (WS-S, WS-I, and WW). Data were subjected to two-way ANOVA: ${ }^{*}{ }^{* *}$, ns indicate significant differences at $P<0.05,0.01$, or not significant. Within root system and water protocol, different letters indicate significant differences (LSD test, $P<0.05$ ).

\begin{tabular}{|c|c|c|c|c|c|c|c|c|c|}
\hline & $\begin{array}{c}\text { Yield } \\
\text { per Vine }\end{array}$ & $\begin{array}{l}\text { Clusters } \\
\text { per Vine }\end{array}$ & $\begin{array}{l}\text { Cluster } \\
\text { Weight }\end{array}$ & $\begin{array}{c}\text { Berry } \\
\text { Weight }\end{array}$ & $\begin{array}{c}\text { Berry } \\
\text { Diameter }\end{array}$ & $\begin{array}{c}\text { Skin } \\
\text { Weight }\end{array}$ & $\begin{array}{c}\text { Seed } \\
\text { Weight }\end{array}$ & $\begin{array}{l}\text { Seeds per } \\
\text { Berry }\end{array}$ & $\begin{array}{c}\text { Pruning } \\
\text { Wood Weight }\end{array}$ \\
\hline & $\mathrm{g}$ & $\mathrm{n}$ & $\mathrm{g}$ & $\mathrm{g}$ & $\mathrm{cm}$ & $\mathrm{g}$ & $\mathrm{g}$ & $\mathrm{n}$ & $\mathrm{g}$ \\
\hline M & 1028 & 12.4 & 79.31 & 1.26 & 1.00 & 0.129 & $0.032 \mathrm{ab}$ & $2.32 \mathrm{a}$ & $123.0 \mathrm{~b}$ \\
\hline $\mathrm{P}$ & 872 & 10.3 & 74.95 & 1.20 & 0.99 & 0.128 & $0.034 \mathrm{~b}$ & $2.19 \mathrm{a}$ & $176.8 \mathrm{c}$ \\
\hline NGC & 715 & 9.1 & 75.04 & 1.21 & 0.99 & 0.132 & $0.029 \mathrm{a}$ & $2.67 \mathrm{~b}$ & $70.2 \mathrm{a}$ \\
\hline WS-S & 943 & 11.4 & 79.59 & 1.25 & 0.98 & $0.149 \mathrm{~b}$ & 0.031 & 2.29 & $99.5 \mathrm{a}$ \\
\hline WS-I & 768 & 10.2 & 72.81 & 1.20 & 0.99 & $0.127 \mathrm{ab}$ & 0.033 & 2.36 & $97 \mathrm{a}$ \\
\hline WW & 904 & 10.2 & 76.89 & 1.23 & 1.00 & $0.110 \mathrm{a}$ & 0.031 & 2.53 & $173.6 \mathrm{~b}$ \\
\hline Root System & ns & ns & ns & ns & $\mathrm{ns}$ & $\mathrm{ns}$ & * & ** & ** \\
\hline Water Protocol & ns & ns & ns & ns & $\mathrm{ns}$ & * & $\mathrm{ns}$ & ns & $* *$ \\
\hline
\end{tabular}

\subsection{Technological Maturity and Phenolic Compound Contents}

The data collected about technological maturity on must show that irrigation regimes significantly affected sugar content $\left({ }^{\circ}\right.$ Brix), titratable acidity ( $\mathrm{g} / \mathrm{L}$ tartaric acid), and $\mathrm{pH}$. In particular, the sugar content was significantly higher in WS-S and WS-I vines, as well as pH values, with significant differences also between the two levels of water stress, with a tendency that increased based on the severity of water limitation; on the contrary, titratable acidity was significantly higher in WW vines compared to the vines subjected to water-stress (both WS-S and WS-I, which showed a similar concentration). No significant differences emerged between the three root systems, therefore the rootstock effect was not detected on any considered parameters (Table 2).

Table 2. Technological maturity and phenolic compound contents (by UV-VIS spectrophotometry) at harvest on grapes of Pinot noir vines grafted on Mgt 101-14 (M), 1103 Paulsen (P), and not grafted vines (NGC), treated with three irrigations protocols (WS-S, WS-I, and WW). Data were subjected to two-way ANOVA: ${ }^{*}{ }^{* *}, * * *$, ns indicate significant differences at $P<0.05,0.01,0.001$, or not significant. Within root system and water protocol, different letters indicate significant differences (LSD test, $P<0.05$ ).

\begin{tabular}{|c|c|c|c|c|c|c|}
\hline & Sugars & $\begin{array}{l}\text { Titratable } \\
\text { Acidity }\end{array}$ & $\mathrm{pH}$ & $\begin{array}{c}\text { Skin } \\
\text { Anthocyanins }\end{array}$ & $\begin{array}{c}\text { Skin } \\
\text { Polyphenols }\end{array}$ & $\begin{array}{c}\text { Seed } \\
\text { Polyphenols }\end{array}$ \\
\hline & ${ }^{\circ}$ Brix & $\mathrm{g} / \mathrm{L}$ tartaric acid & & $\mathrm{mg} / \mathrm{kg}$ grapes & $\mathrm{mg} / \mathrm{kg}$ grapes & $\mathrm{mg} / \mathrm{kg}$ grapes \\
\hline \multicolumn{7}{|l|}{ Root System } \\
\hline $\mathrm{M}$ & 20.7 & 5.69 & 3.21 & 871 a & 1556 a & 4117 a \\
\hline $\mathrm{P}$ & 20.2 & 5.73 & 3.19 & $1034 \mathrm{~b}$ & $1753 \mathrm{~b}$ & $4872 \mathrm{~b}$ \\
\hline NGC & 21.0 & 5.62 & 3.17 & $945 \mathrm{ab}$ & $1583 \mathrm{a}$ & $4188 \mathrm{a}$ \\
\hline \multicolumn{7}{|l|}{ Water Protocol } \\
\hline WS-S & $22.4 \mathrm{c}$ & $5.35 \mathrm{a}$ & $3.30 \mathrm{c}$ & 1146 c & $1738 \mathrm{~b}$ & $4782 \mathrm{~b}$ \\
\hline WS-I & $21.0 \mathrm{~b}$ & $5.32 \mathrm{a}$ & $3.20 \mathrm{~b}$ & $1002 b$ & $1798 \mathrm{~b}$ & $4431 \mathrm{~b}$ \\
\hline WW & $18.5 \mathrm{a}$ & $6.38 \mathrm{~b}$ & $3.07 \mathrm{a}$ & $703 a$ & $1357 \mathrm{a}$ & $3963 \mathrm{a}$ \\
\hline Root System & ns & ns & ns & $*$ & $*$ & $* *$ \\
\hline Water Protocol & $* * *$ & $* * *$ & $* * *$ & $* * *$ & $* * *$ & $* *$ \\
\hline $\mathrm{A} \times \mathrm{B}$ & ns & ns & ns & ns & ns & ns \\
\hline
\end{tabular}


About phenolic contents detected by UV-VIS spectrophotometry on grape extracts, significant differences arose regarding the accumulation of skin polyphenols, seed polyphenols, and skin anthocyanins (expressed in $\mathrm{mg} / \mathrm{kg}$ of grapes) depending on both the irrigation protocol and rootstock. The grapes subjected to water stress (WS-S and WS-I, equally) showed a higher content of polyphenols in seeds and skins as well as a higher content of anthocyanins in the skins; in this case, the three irrigation protocols were clearly separated, with the maximum concentration reached by the vines subjected to WS-S, the most severe level of water stress. Similarly, the vines grafted on $P$ accumulated a higher concentration of polyphenols in skins and seeds and anthocyanins in the skins (Table 2).

On berry skin extracts, additional analyses were performed by HPLC to separate the anthocyanin profiles and other classes of phenolic compounds (Tables 3 and 4).

Regarding the anthocyanins profiles, HPLC results confirmed the absence of acylated anthocyanins, as typical of Pinot noir grapes [49]. Analyzing the anthocyanin composition of all the samples considered, some differences emerged in the percentage of the five individual anthocyanins contributing to the profile (Table 3). The content of trisubstituted or disubstituted anthocyanins was found to be significantly different due to both root system and irrigation protocol. In particular, the vines grafted on 1103 Paulsen had the highest content in trisubstituted anthocyanins due to a higher accumulation of malvidin, while the vines grafted on Mgt 101-14 and not grafted had higher values of disubstituted anthocyanins, due to a higher accumulation of cyanidin and peonidin. Consequently, the ratio between disubstituted and trisubstituted anthocyanins was also significantly different. Furthermore, the amount of available water during the water stress trial also affected the same parameters of anthocyanin profiles. The WS-S vines, namely those subject to the most severe water stress treatment, had a higher content of disubstituted anthocyanins due to an increased accumulation of peonidin, while the WS-I and WW vines were similar, with a higher content of trisubstituted anthocyanins, due to an increased accumulation of delphinidin, petunidin, and malvidin (the latter only in WW vines).

The separation of phenolic compound classes, as detected at specific wavelengths by HPLC, gave some interesting results (Table 4). Some differences emerged in the content of the catechins, due to the root system only; no difference was determined by the water supply. In particular, the vines grafted on rootstock $\mathrm{M}$ had the highest concentration of procyanidin B1 and epicatechin in their berry skins, and the lowest concentration was in not grafted vines (NGC). No significant differences arose in the accumulation of flavonols in berry skins, due to neither the root system nor the irrigation protocol. Regarding the quantity of hydroxycinnamoyl tartaric acids (HCTA), the root system has determined some differences in the content of trans-caftaric acid and trans-fertaric acid; here too, the highest concentrations were in the grapes coming from vines grafted on the M rootstock and the lowest in not grafted vines (NGC). Finally, the stilbenes content also had significant differences in some compounds due to the water supply (resveratrol) or both the root system and water supply (trans- $\varepsilon$-viniferin). Resveratrol and trans- $\varepsilon$-viniferin were more accumulated in the vines subjected to severe water deficit. Moreover, a higher content of trans- $\varepsilon$-viniferin was found in $\mathrm{M}$ vines (Table 4).

According to the statistical analyses carried out, the interaction of root system $\times$ water protocol did not have a statistically significant effect on technological maturity or phenolic compound contents, confirming that the differences were caused by the individual factors considered. 
Table 3. Anthocyanin profiles by HPLC of berry skins of Pinot noir vines grafted on Mgt 101-14 (M), 1103 Paulsen (P), and not grafted vines (NGC), treated with three irrigations protocols (WS-S, WS-I, and WW). Data were subjected to two-way ANOVA: ${ }^{*}{ }^{* * *}$, ns indicate significant differences at $P<0.05,0.001$, or not significant. Within root system and water protocol, different letters indicate significant differences (Bonferroni test, $P<0.05$ ).

\begin{tabular}{|c|c|c|c|c|c|c|c|c|}
\hline & Delphindin & Cyanidin & Petunidin & Peonidin & Malvidin & $\begin{array}{l}\text { Trisubstituted } \\
\text { Anthocyanins }\end{array}$ & $\begin{array}{l}\text { Disubstituted } \\
\text { Anthocyanins }\end{array}$ & $\begin{array}{c}\text { Trisubstituted } \\
\text { Disubstituted Ratio }\end{array}$ \\
\hline & $\%$ & $\%$ & $\%$ & $\%$ & $\%$ & $\%$ & $\%$ & \\
\hline \multicolumn{9}{|l|}{ Root System } \\
\hline $\mathrm{M}$ & $4.47 \mathrm{~b}$ & $2.21 \mathrm{~b}$ & $6.25 \mathrm{~b}$ & $29.15 b$ & $57.93 \mathrm{a}$ & $68.64 \mathrm{a}$ & $31.36 \mathrm{~b}$ & $2.21 \mathrm{a}$ \\
\hline $\mathrm{P}$ & $3.69 \mathrm{a}$ & $1.43 \mathrm{a}$ & $5.56 \mathrm{a}$ & $23.96 \mathrm{a}$ & $65.36 \mathrm{~b}$ & $74.61 \mathrm{~b}$ & $25.39 \mathrm{a}$ & $3.19 \mathrm{~b}$ \\
\hline NGC & $3.77 \mathrm{a}$ & $2.03 \mathrm{~b}$ & $5.56 \mathrm{a}$ & $28.71 \mathrm{~b}$ & $59.94 \mathrm{a}$ & $69.26 \mathrm{a}$ & $30.74 b$ & $2.41 \mathrm{a}$ \\
\hline \multicolumn{9}{|l|}{ Water Protocol } \\
\hline WS-S & $3.61 \mathrm{a}$ & 1.92 & $5.40 \mathrm{a}$ & $30.24 b$ & $58.83 \mathrm{a}$ & $67.84 \mathrm{a}$ & $32.16 \mathrm{~b}$ & $2.20 \mathrm{a}$ \\
\hline WS-I & $4.15 \mathrm{~b}$ & 1.85 & $6.03 \mathrm{~b}$ & $26.16 \mathrm{a}$ & $61.81 \mathrm{ab}$ & $71.99 \mathrm{~b}$ & $28.01 \mathrm{a}$ & $2.74 \mathrm{ab}$ \\
\hline WW & $4.15 \mathrm{~b}$ & 1.90 & $5.94 \mathrm{~b}$ & $25.42 \mathrm{a}$ & $62.59 \mathrm{~b}$ & $72.68 \mathrm{~b}$ & $27.32 \mathrm{a}$ & $2.87 \mathrm{~b}$ \\
\hline Root System & * & $* * *$ & * & $*$ & * & * & * & * \\
\hline Water Protocol & $*$ & ns & * & $*$ & $*$ & $*$ & $*$ & $*$ \\
\hline $\mathrm{A} \times \mathrm{B}$ & ns & ns & ns & ns & ns & ns & ns & ns \\
\hline
\end{tabular}


Table 4. Phenolic compounds detected by HPLC in berry skins of Pinot noir vines grafted on Mgt 101-14 (M), 1103 Paulsen (P), and not grafted vines (NGC), treated with three irrigations protocols (WS-S, WS-I, and WW). Data were subjected to two-way ANOVA: ${ }^{*}$, ns indicate significant differences at $P<0.05$, or not significant. Within root system and water protocol, different letters indicate significant differences (LSD test, $P<0.05$ ).

\begin{tabular}{|c|c|c|c|c|c|c|c|c|}
\hline & Procynidin B1 & Epigallocatechin & Catechin & Epicatechin & Quercetin & Myricetin & Kaempferol & Isorhamnetin \\
\hline & HPLC Area & HPLC Area & HPLC Area & HPLC Area & HPLC Area & HPLC Area & HPLC Area & HPLC Area \\
\hline \multicolumn{9}{|l|}{ Root System } \\
\hline M & $62 \mathrm{~b}$ & 49 & 26 & $35 \mathrm{~b}$ & 2262 & 1195 & 205 & 114 \\
\hline $\mathrm{P}$ & $53 \mathrm{ab}$ & 43 & 34 & $26 \mathrm{a}$ & 1992 & 1056 & 177 & 112 \\
\hline NGC & $45 \mathrm{a}$ & 38 & 24 & $26 \mathrm{a}$ & 2154 & 985 & 205 & 110 \\
\hline \multicolumn{9}{|l|}{ Water Protocol } \\
\hline WS-S & 55 & 41 & 21 & 33 & 1957 & 1080 & 212 & 118 \\
\hline WS-I & 51 & 41 & 25 & 28 & 2066 & 1017 & 170 & 104 \\
\hline WW & 54 & 47 & 37 & 26 & 2385 & 1139 & 206 & 113 \\
\hline Root System & $*$ & ns & ns & $*$ & ns & ns & ns & ns \\
\hline Water Protocol & ns & ns & ns & ns & ns & ns & ns & ns \\
\hline \multirow[t]{3}{*}{$\mathrm{A} \times \mathrm{B}$} & ns & ns & ns & ns & ns & ns & ns & ns \\
\hline & Protocatechuic Acid & Trans-Caftaric Acid & Cis-Coutaric Acid & Trans-Coutaric Acid & Trans-Fertaric Acid & Polydatin & Resveratrol & Trans- $\varepsilon$-Viniferin \\
\hline & HPLC Area & HPLC Area & HPLC Area & HPLC Area & HPLC Area & HPLC Area & HPLC Area & HPLC Area \\
\hline \multicolumn{9}{|l|}{ Root System } \\
\hline $\mathrm{M}$ & 18 & $27 \mathrm{~b}$ & 155 & 112 & $39 \mathrm{~b}$ & 355 & 128 & $7 \mathrm{~b}$ \\
\hline $\mathrm{P}$ & 15 & $24 \mathrm{ab}$ & 113 & 94 & $29 \mathrm{ab}$ & 287 & 101 & $5 \mathrm{a}$ \\
\hline NGC & 16 & $22 \mathrm{a}$ & 111 & 98 & 26 a & 373 & 106 & $6 \mathrm{ab}$ \\
\hline \multicolumn{9}{|l|}{ Water Protocol } \\
\hline WS-S & 19 & 25 & 120 & 104 & 34 & 348 & $137 \mathrm{~b}$ & $8 \mathrm{~b}$ \\
\hline WS-I & 16 & 24 & 124 & 98 & 28 & 320 & $86 \mathrm{a}$ & $5 \mathrm{a}$ \\
\hline WW & 14 & 24 & 135 & 103 & 31 & 347 & $112 \mathrm{ab}$ & $6 \mathrm{ab}$ \\
\hline Root System & ns & $*$ & ns & ns & $*$ & ns & ns & * \\
\hline Water Protocol & ns & ns & ns & ns & ns & ns & * & * \\
\hline $\mathrm{A} \times \mathrm{B}$ & ns & ns & ns & ns & ns & ns & ns & ns \\
\hline
\end{tabular}




\section{5. qRT-PCR Analyses of Gene and miRNA Expressions}

qRT-PCR reactions were executed to assess the expression levels of specific genes and miRNAs and to check for any transcript differences due to early water stress. The ten genes studied are all involved in some key points of the phenylpropanoid pathway, as structural genes or genes coding for transcription factors belonging to MYB and NAC gene families; the five miRNAs are involved in the regulation of secondary metabolism or stress response. The values obtained and shown in Figures 5 and 6 are the Log2 Fold Changes of expression, referred to the sample NGC-WW, treated as control; and statistical analyses were performed to validate our results.

The VvPAL gene (VIT_13s0019g04460) encodes a phenylalanine ammonia-lyase, the enzyme responsible for the first step of the phenylpropanoid pathway [50]. A faint upregulation is observed under severe water stress in NGC and in the vines grafted on P (Figure 5A).

Both copies of the $V v F 3^{\prime} H$ genes (VIT_209s0002g01090 and VIT_217s0000g07200) present in the grapevine genome [51] were analyzed. They encode for two isoforms of flavonoid 3 '-hydroxylase, an enzyme responsible for the bifurcation of the metabolic pathway of anthocyanins synthesis by competing with F3' $5^{\prime} \mathrm{H}$ (flavonoid 3', 5' -hydroxylase) for substrate recruitment; F3' $\mathrm{H}$ and F3' $5^{\prime} \mathrm{H}$ deliver $3^{\prime} \mathrm{OH}$ or $3^{\prime}, 5^{\prime} \mathrm{OH}$ products, namely trisubstituted or disubstituted anthocyanins, precursors of red and blue skin pigments, respectively [52]. From our results, it emerged that while the transcript profile of $V v F 3^{\prime} H$ A (VIT_209s0002g01090) is not significantly differentially expressed, probably due to the variation among biological replicates (Figure 5B), the other transcript, VvF3'H B (VIT_217s0000g07200), was modulated under water stress. F3' $\mathrm{H} B$, not detected as differentially expressed among the three root systems in WW conditions, showed under water stress a faint but statistically significant upregulation in NGC vines and a more marked downregulation in the vines grafted on P (Figure 5C).

The VvFLS gene (VIT_18s0001g03430) encodes a flavonol synthase, a key enzyme in flavonol biosynthesis [53]. From the data obtained, in the grafted vines, the presence of $F L S$ transcript was increased in WS-S compared to WW, in particular in P berry skins, while, in NGC, the expression was considerably lower in WS-S than in WW (Figure 5D).

The VvDFR gene (VIT_16s0039g02350) carries out the first step of anthocyanidin synthesis and competes with FLS for substrate availability [52]. The results obtained show a significant upregulation in all the three root systems in WS-S compared to WW vines. In particular, NGC vines had a tripled expression compared to the control, while smaller differences emerged in both the grafted $\mathrm{M}$ and $\mathrm{P}$ vines (Figure 5E).

Among the considered MYB genes (Figure $5 \mathrm{~F}-\mathrm{H}$ ), the $V v M Y B C 2-L 3$ gene that acts a transcriptional repressor in the synthesis of anthocyanins and proanthocyanidins [54], is the only one showing significant differential expression. All the three root systems displayed a significant downregulation of MYBC2-L3 under water stress, with a sharper expression decrease in grafted vines (Figure 5G).

The VvNAC44 gene, involved in berry ripening and stress response [55], was significantly differentially expressed in all the root system combinations, with higher expression in WS-S (threefold in M, fivefold in P, and nearly sevenfold in NGC) compared to irrigated controls (Figure 5I).

Finally, the $V v N A C 60$ gene, considered a master regulator in the transition from unripe to ripe grape berries [56], was observed as upregulated in P-WS-S, but above all in NGC-WS-S vines, while no differences between WS-S and WW were found in the M vines (Figure $5 \mathrm{~J}$ ).

Hence, the application of early water stress caused lasting effects on grape quality, manifested by altered gene expression in berry skins at maturity.

miR395 is known to be involved in stress response [57] acting in the phenylpropanoid pathway [58]. This miRNA was differently expressed in WW conditions among the three root systems, in particular between plants grafted on M and P, and, under severe stress conditions (WS-S), it was found as downregulated in M-WS-S vines and upregulated in P-WS-S vines, showing an opposite behavior among the two rootstocks considered. In NGC, almost no differences were detected between the two irrigation levels (Figure 6A). 

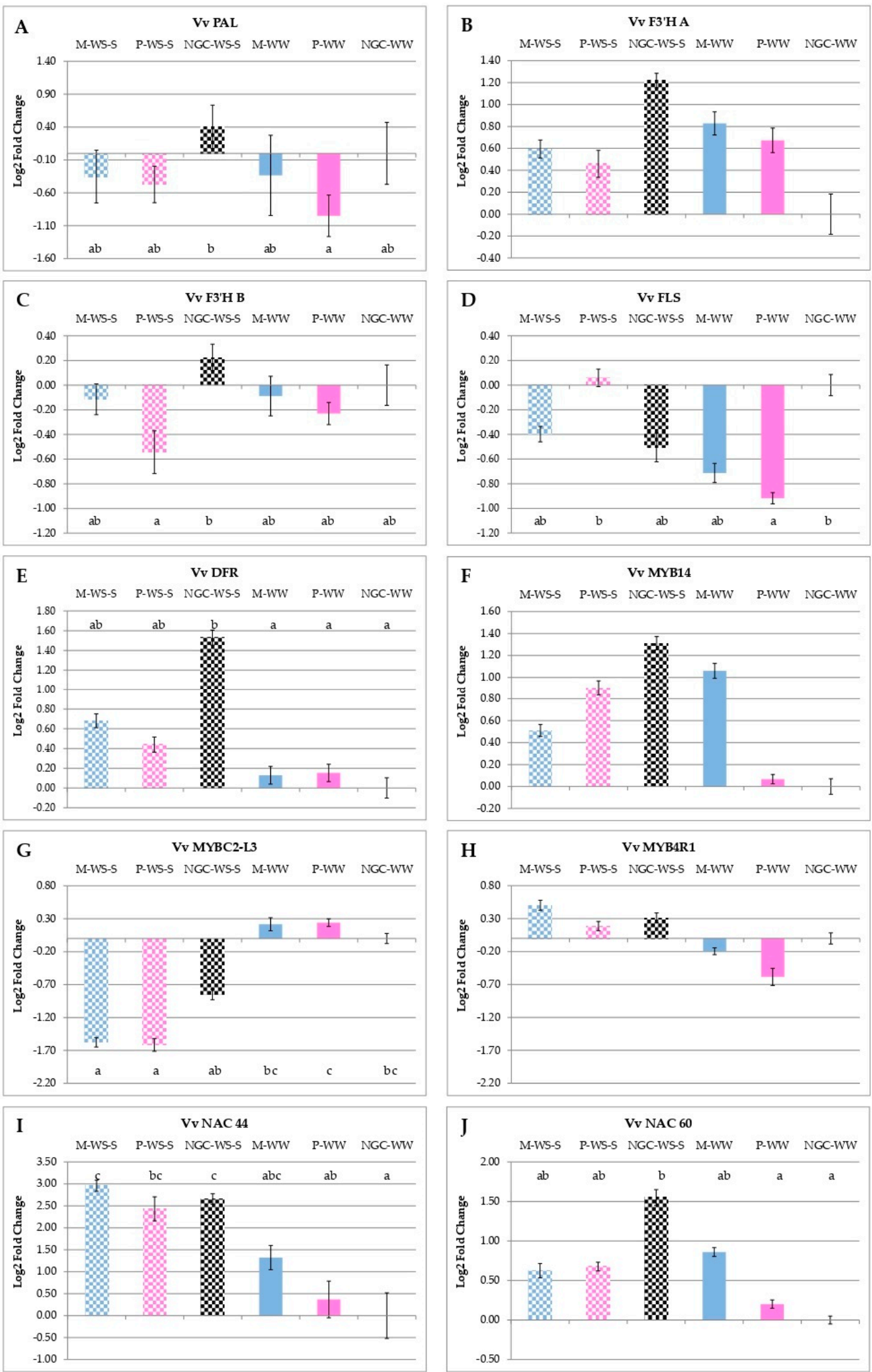

Figure 5. Expression profiles of the ten selected genes coding for structural genes and transcription factors obtained by qRT-PCR. Log2 Fold Change, calculated with the $\triangle \triangle \mathrm{Ct}$ method, of $V v P A L$ (A), 
$V v F 3^{\prime} H$ A (B), $V v F 3^{\prime} H$ B (C), VvFLS (D), VvDFR (E), VvMYB14 (F), VvMYBC2-L3 (G), VvMYB4R1 $(\mathbf{H}), V v N A C 44(\mathbf{I})$, and $V v N A C 60(\mathbf{J})$. The error bars indicate the standard deviation. Sample names: M-WS-S, vines grafted on Mgt 101-14 subjected to severe water stress (in checkered light blue); P-WS-S, vines grafted on 1103 Paulsen subjected to severe water stress (in checkered pink); NGC, not grafted control vines subjected to severe water stress (in checkered black); M-WW, well-watered vines grafted on Mgt 101-14 (in light blue); P-WW, well-watered vines grafted on 1103 Paulsen (in pink); NGC-WW, well-watered not grafted vines (control). Different letters indicate significant differences (LSD test, $P<0.05)$.
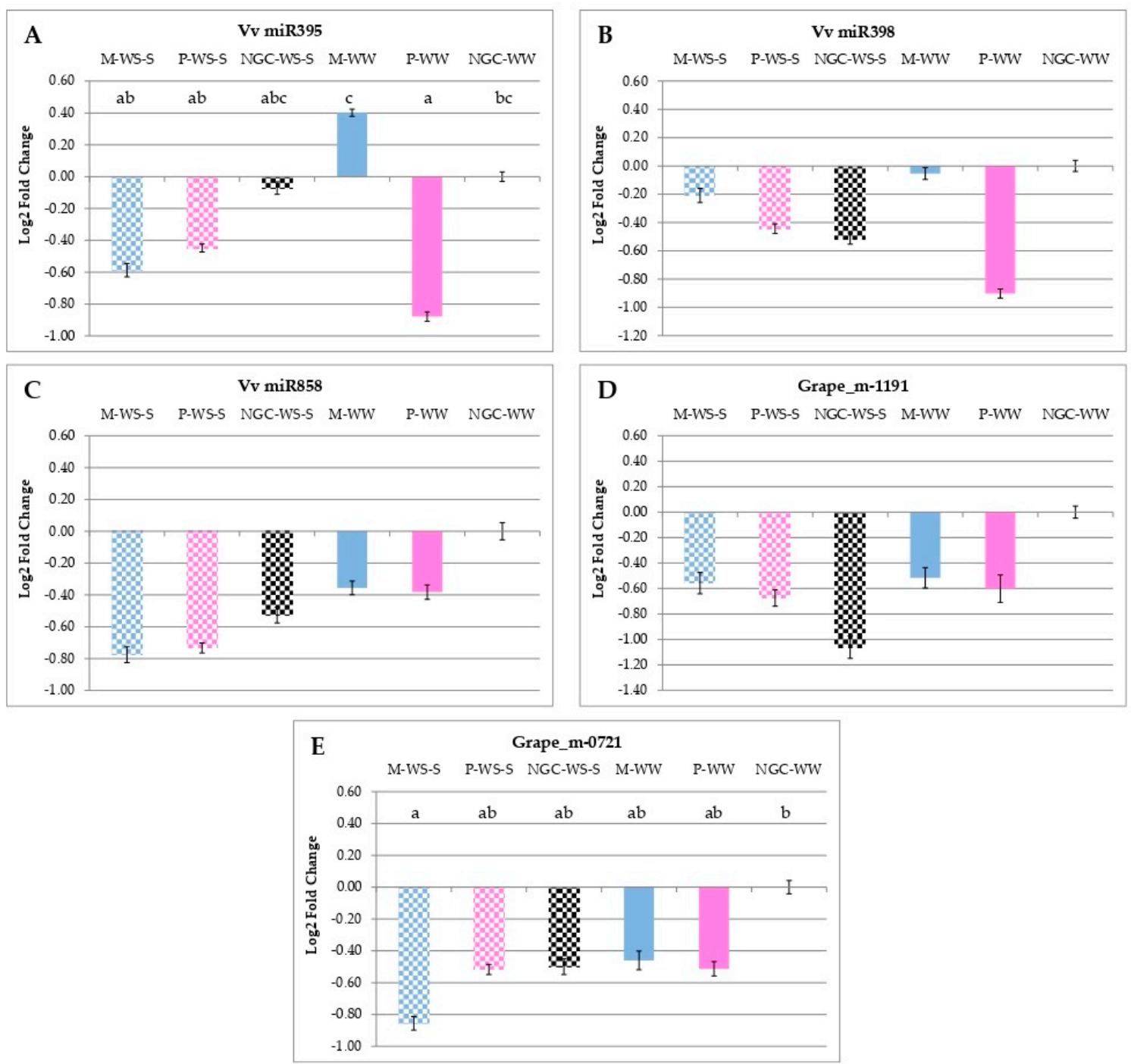

Figure 6. Expression profiles of the five selected miRNAs obtained by qRT-PCR. Log2 Fold Change, calculated with the $\Delta \Delta$ Ct method, of miR395 (A), miR398 (B), miR858 (C), Grape_m-1191 (D), and Grape_m-0721 (E). The error bars indicate the standard deviation. Sample names: M-WS-S, vines grafted on Mgt 101-14 subjected to severe water stress (in checkered light blue); P-WS-S, vines grafted on 1103 Paulsen subjected to severe water stress (in checkered pink); NGC, not grafted control vines subjected to severe water stress (in checkered black); WS, water stress; M-WW, well-watered vines grafted on Mgt 101-14 (in light blue); P-WW, well-watered vines grafted on 1103 Paulsen (in pink); NGC-WW, well-watered not grafted vines (control). Different letters indicate significant differences (LSD test, $P<0.05$ ). 
Grape_m-0721, a grapevine specific miRNA that has some functional genes of secondary metabolism as targets [59], showed a clear downregulation in case of water deficit in NGC and $\mathrm{M}$ vines, while no differences are observed in vines grafted on $\mathrm{P}$ (Figure 6E).

Other miRNAs evaluated did not show any significant modulation of their expression in the considered system (Figure 6B-D), putatively because of the high variability in the biological replicates used and the small fluctuation in gene expression due to water stress.

\section{Discussion}

The present research work was conceived to investigate the role of two rootstocks, with opposite characteristics in terms of resistance to drought and vigor given to the scion, on berry quality in grapes that have undergone early water stress, between cluster closure and veraison. A water stress trial was set up to highlight the differences given by the two tested rootstocks (Mgt 101-14 (M) and 1103 Paulsen (P)) on the production and quality of the grapes, compared to not grafted vines (NGC). The stress trial was applied during the first phase of berry growth (Phase I, or herbaceous phase), since it is known that, unlike stress occurring in post-veraison (Phase II, or ripening phase), it can have remarkable effects, both at the biochemical and molecular level $[20,45,60,61]$. These consequences are well detectable even after a long time from the end of the stress, on berry characteristics, or on the accumulation of some primary and secondary metabolites (such as sugar contents, anthocyanins, resveratrol) at maturity when the grapes are ready to be used for vinification. The activity was carried out using an experimental system of potted Pinot noir vines, as in [24], conceived to simulate the open field conditions while controlling many external variables, primarily water availability, and improve the quality of the phenotyping activities. The cultivar Pinot noir clone ENTAV115 was specifically chosen as its genome is fully sequenced and annotated [62,63]. Moreover, the use of pots made it possible to insert not grafted vines as a control, normally not employable in a commercial vineyard.

The results obtained from the measurements on grapevine physiology (Figures 2-4) confirm the onset of water stress, highlighting the presence of two different levels, dictated by severe (WS-S) and intermediate (WS-I) water deficits, as established by the experimental plan $[46,64,65]$. Besides, the rootstocks showed some significant effects on leaf gas exchanges ( $g s, \mathrm{~A}$, and E) only during the first phase of water deficit (as shown at DOY 194), while before and after the water stress trial no differences were detected (Figure 3D-F).

\subsection{The Root System and Water Supply Did Not Affect Grape Production, but Water Deficit Had a Strong Influence on the Technological Maturity}

Although it is well known that water deficit affects grape production in terms of both yield and quality, results in the literature are often contradictory and highlight dissimilar physiological responses depending on grapevine variety and cultivation environment [66].

From the obtained results, no differences emerged in yield per vine, cluster number, and weight, and berry weight and diameter of the vines subjected to severe (WS-S) and intermediate (WS-I) water deficits (Table 1). Therefore, it can be deduced that, in our experimental system, the grape production was affected neither by the irrigation protocol nor by the root system. According to our experience, and also as argued by other authors [46-48], we assumed that radical confinement may have had a strong impact on yields, flattening the differences between samples. Otherwise, a plausible explanation about the absence of significant different berry weights among the samples, which is supported by the measurements on vine physiology at DOY 208 (Figures 2-4), is that the vines have undergone thermal and/or radiative stress due to a heatwave $[43,44]$ during berry development (Phase I) that inhibited the growth by cell division $[8,9,43,67]$.

Beyond this, it was noted that the vines that suffered severe water stress had a higher skin weight, the only effective difference that occurred due to water protocol. Instead, the number and weight of the seeds were determined solely by the type of root system (Table 1). Considering that seed development 
is influenced by cytokinins, hormones produced in the roots [61], the parameters found as differentially significant were likely to be influenced by rootstock, as already established by other authors [68].

A parameter found to be significantly different was the pruning wood weight (Table 1), which was influenced by both rootstock and irrigation protocol factors. The highest values, in particular, were obtained under optimal irrigation conditions (WW) and for the vines grafted on 1103 Paulsen, a rootstock that is known to confer high vigor in the scion, due to its geotropic angle characteristics and radical deepening ability [26,69]. The influence of 1103 Paulsen was clearly visible, in this case, despite the pot confinement of the roots. On the contrary, the quantity of wood biomass produced by not grafted vines (NGC) was very low, which presented less than half of the weight compared to $P$ vines. This result is akin to others found in the literature, where it is shown that own-rooted can have a lower vigor than grafted vines [70,71]. As regards technological maturity, the different water supplies strongly conditioned the accumulation of sugars $\left({ }^{\circ}\right.$ Brix), the titratable acidity ( $\mathrm{g} / \mathrm{L}$ tartaric acid), and the $\mathrm{pH}$ in the berries (Table 2) confirming previous studies on Pinot noir [72]. On the contrary, no influence given by rootstock type was highlighted on technological maturity parameters. As previously seen on the same experimental system [24], grafting on Mgt 101-14 and 1103 P rootstocks did not affect the primary metabolism of Pinot noir potted grapevines. This also can be due to the condition of pot-growth, where the vines were not as efficient as in the open field, and the differences could have been compressed.

\subsection{Phenolic Compounds Accumulation was Influenced in Berries Both by Water Supply and Root System}

From the analyses on berry extracts, we found that the vines subjected to water stress (in both WS-S and WS-I protocols) accumulated more total polyphenols in the tissues considered (skin and seed), and had a higher concentration of total anthocyanins in the skins (Table 2). Even the rootstock factor had a significant influence on these parameters. In fact, in the vines grafted on 1103 Paulsen, the influence given by this most drought-tolerant rootstock was clearly detected in the accumulation of secondary metabolites in grape skins and seeds, which was significantly greater than in the other two root systems.

The HPLC analyses on secondary metabolites in berry skins performed to obtain a detailed description of the different phenylpropanoid compounds accumulated, showed important differences in the anthocyanin profile, which was significantly altered by both root system and water protocol (Table 3). Interestingly, it is important to note that the vines grafted on 1103 Paulsen showed a higher content of trisubstituted anthocyanins in berry skins (with similar behavior in the vines subjected to WS-I and WW irrigation protocols). Anthocyanins are the molecules responsible for the color of grapes and, although each cultivar has a conserved and distinctive anthocyanin profile, it can vary considerably depending on the environmental conditions [73]. The alternative accumulation of trisubstituted rather than disubstituted anthocyanins is due to a bifurcation in the anthocyanin synthesis pathway and is linked to the competitive activity of $\mathrm{F}^{\prime} \mathrm{H}$ and $\mathrm{F}^{\prime} 5^{\prime} \mathrm{H}$ [74]. The presence of higher contents of trisubstituted anthocyanins favors greater resistance to oxidative damage [75]. In addition, from an oenological point of view, higher concentrations of trisubstituted anthocyanins in berry skins are desirable, especially in grapes lacking acylated anthocyanins, such as Pinot noir and Sangiovese [49], since malvidin-like anthocyanins confer greater color stability in red wines and better aging aptitude [76].

The results about phenolic compounds show that the concentrations of some chemical classes were significantly influenced by the root systems, with higher concentrations in the grapes produced by $\mathrm{M}$ vines. Assuming that from an oenological point of view these concentrations would have a very small impact on the final grape quality, this trend might be due to a greater attitude of the $M$ rootstock, as drought-susceptible, to trigger a strong synthesis of secondary compounds such as some catechins or HCTA, as a response to stress. On the contrary, the P vines likely used the intermediate substrates of the phenylpropanoid pathway to synthesize other phenolic compound classes, such as 
anthocyanins. Other similar studies have established that there is an influence of the rootstock on the phenolic composition of the grapes [77].

As for stilbenes (Table 4), the concentration of resveratrol (3,5,4'-trihydroxy-trans-stilbene), the main stilbene in grapes, and trans- $\varepsilon$-viniferin (a cyclic oligomer of resveratrol) was favored by the severe water deficit (WS-S), confirming that these molecules play a key role in the response to abiotic stress and their concentration in grapes is generally low, but it can burst in the case of pathogen attacks or at the presence of limiting factors [78]. Furthermore, trans- $\varepsilon$-viniferin was accumulated in higher quantities in berry skins of the vines grafted on M rootstock. The accumulation mechanisms of stilbenes (especially resveratrol) can be considered very interesting because these molecules have attracted the attention of the scientific community for their pharmacologic properties in preventing human diseases [79].

Our results are in agreement with many published papers demonstrating that water deficit significantly affects the accumulation of polyphenols in grapes, with skin anthocyanins that normally show higher sensitivity to a possible water shortage $[17,19,75]$.

\subsection{Early Water Stress Modulated the Expression of Genes and miRNAs Involved in Secondary Metabolism with Lasting Effects, Still Evident at Maturity}

The genes and miRNAs studied in the present work by qRT-PCR were already detected as moderately differentially expressed between vines having different root systems ( $M, P$, and NGC) in conditions of optimal irrigation [24]. Therefore, the goal of this analysis was to monitor at maturity, besides biochemical parameters, the molecular response in berry skins due to early prolonged water stress. The comparison of gene and miRNA expression was carried out between berry skin samples at maturity subjected to severe stress (WS-S) and well-watered (WW). The results acquired show that the period of pre-veraison water shortage still had an effect on gene/miRNA expression in berry skins at maturity (Figures 5 and 6). The major evidence emerged in the expression patterns of MYBC2-L3 and NAC transcription factors, which were strongly modulated (generally upregulated in WS-S, with an opposite trend for the repressor MYBC2-L3) according to vine water status. Besides, our results are in accordance with other findings that demonstrated that $V v N A C$ genes display a stress-inducible upregulation [80]. In addition, in other species, for example rice (Oryza sativa) and soybean (Glycine max), the overexpression of NAC transcription factors can enhance drought resistance [81,82].

Some specific miRNAs, non-coding small RNAs (19-24 nucleotides long) that perform post-transcriptional gene silencing in plants [83-85] were included in this study since, in Vitis vinifera, it has been demonstrated that grafting can alter miRNAs abundance in the scion, causing changes in the final phenotype $[86,87]$. The results show that, in the comparison between WW and WS-S, among the five miRNAs considered, only two (miR395 and Grape_m-0721) resulted differentially expressed in at least one of the three root systems (Figure 6A-E). According to the literature, miR395 is significantly upregulated in the presence of drought stress in Oryza sativa [88]. In our data, miR395 showed an opposite trend of expression between the two grafted plants, while it did not show any modulation in NGC plants. In vines grafted on 1103 Paulsen, the most drought-resistant rootstock, miR395 had a higher expression in WS-S vs WW irrigation protocols, while, on the contrary, it was downregulated in vines grafted on $\mathrm{M}$.

Grape_m-0721 is a species-specific miRNA identified in previous papers $[89,90]$ and targeting, among others, an anthocyanin 5-aromatic acyltransferase-like (VIT_213s0064g01165), a sterol oxidase (VIT_213s0019g02210), and an anthocyanidin 5,3-O-glucosyltransferase (VIT_216s0050g00240), all genes involved in secondary metabolism. For this reason, it was included and tested in the present work and, interestingly, here we observed a downregulation of its expression in NGC and M vines, but not in plants grafted on 1103 Paulsen. The role of this grapevine specific small RNA still has to be clarified, and even if we reckon that a small variation of its expression might not be biologically significant, we can putatively suggest a role in regulating anthocyanin modification under drought stress. 


\section{Conclusions}

By adopting an integrated biochemical and molecular approach, the research allowed testing the rootstock influence on vine productivity and grape quality under water stress conditions. According to the results obtained in our experimental system, the water-stressed vines remained productive, probably due to pot-induced limitations that flattened differences in yields between samples, but berry quality was considerably altered in comparison to the vines grown with abundant water availability. From our results, a direct influence of the rootstocks on water stress resistance was not detected on physiological parameters during the stress period, or in terms of yield and berry characteristics at maturity, but secondary metabolism was significantly modulated in grapes. In particular, in the vines grafted on 1103 Paulsen, a rootstock genotype that is known to confer higher drought tolerance in the scion, the carbon flux was driven towards the accumulation of phenolic compounds, especially noticeable in the alteration of the anthocyanin profile.

qRT-PCR data show the alteration in gene expression caused by early water deficit, clearly evident even after weeks from stress, and underline the role of gene regulation (transcription factors and miRNAs) within secondary metabolism as a vine response to mitigate water stress.

The results that emerged from our study suggest a rootstock-dependent response in the case of water stress, which prominently impacted on grape quality at harvest.

Supplementary Materials: The following are available online at http://www.mdpi.com/2073-4395/10/5/680/s1, Table S1: List of forward, reverse and stem-loop reverse transcriptase primers used for qRT-PCR to test genes and miRNAs expression; Table S2: Midday stem water potentials ( $\left.\Psi_{\text {stem }}\right)$; Table S3: Leaf gas exchange: stomatal conductance (gs); Table S4: Leaf gas exchange: net assimilation (A); Table S5: Leaf gas exchange: leaf transpiration (E); Table S6: Chlorophyll fluorescence (Fv/Fm).

Author Contributions: Conceptualization, A.Z., P.S., and G.B.M.; Methodology, A.Z., E.M., S.P., and R.P.; Validation, A.Z., P.V., S.P., and E.M.; Formal analysis, A.Z., P.V., and S.P.; Investigation, A.Z., S.P., P.V., and R.P.; Resources, R.P. and P.S.; Data curation, A.Z., E.M., and S.P.; Writing—original draft preparation, A.Z.; Writing - review and editing, E.M., L.C., P.S., and G.B.M.; Visualization, A.Z. and E.M.; and Supervision, P.S., L.C., and G.B.M. All authors have read and agreed to the published version of the manuscript.

Funding: This research received no external funding.

Acknowledgments: The authors thank the colleagues of CREA (Research Centre for Agriculture and Environment) (Florence, Italy), Edoardo A.C. Costantini, and Simone Priori for designing and setting up the experimental pot system used in this work. We also thank the colleagues of CREA (Research Centre for Viticulture and Enology) (Arezzo, Italy) for their help in samplings, laboratory work, and agronomic management of the grapevines.

Conflicts of Interest: The authors declare no conflict of interest.

\section{References}

1. Jones, G.V.; White, M.A.; Cooper, O.R.; Storchmann, K. Climate change and global wine quality. Clim. Change 2005, 73, 319-343. [CrossRef]

2. Chaves, M.M.; Zarrouk, O.; Francisco, R.; Costa, J.M.; Santos, T.; Regalado, A.P.; Rodrigues, M.L.; Lopes, C.M. Grapevine under deficit irrigation: Hints from physiological and molecular data. Ann. Bot. 2010, 105, 661-676. [CrossRef] [PubMed]

3. Goode, J. Viticulture: Fruity with a hint of drought. Nature 2012, 492, 351-352. [CrossRef] [PubMed]

4. Masson-Delmotte, V.; Zhai, P.; Portner, H.-O.; Roberts, D.; Skea, J.; Shula, P.R.; Pirani, A.; Moufouma-Okia, W.; Pean, C.; Pidcock, R.; et al. Global Warming of $1.5^{\circ} \mathrm{C}$. An IPCC Special Report on the Impacts of Global Warming of $1.5^{\circ} \mathrm{C}$ above Pre-Industrial Levels and Related Global Greenhouse Gas Emission Pathways, in the Context of Strengthening the Global Response to the Threat of Climate Change, Sustainable Development, and Efforts to Eradicate Poverty; Intergovernmental Panel on Climate Change: Geneva, Switzerland, 2018; ISBN 978-92-9169-151-7.

5. Peterlunger, E.; Sivilotti, P.; Colussi, V. Water stress increased polyphenolic quality in 'Merlot' grapes. Acta Hortic. 2005, 689, 293-300. [CrossRef]

6. Van Leeuwen, C.; Tregoat, O.; Choné, X.; Bois, B.; Pernet, D.; Gaud-illère, J.P. Vine water status is a key factor in grape ripening and vintage quality for red Bordeaux wine. How can it be assessed for vineyard management purposes? OENO One 2009, 43, 121-134. [CrossRef] 
7. Ferrandino, A.; Lovisolo, C. Abiotic stress effects on grapevine (Vitis vinifera L.): Focus on abscisic acid-mediated consequences on secondary metabolism and berry quality. Environ. Exp. Bot. 2014, 103, 138-147. [CrossRef]

8. Fraga, H.; Malheiro, C.; Moutinho-Pereira, J.; Santos, J.A. An overview of climate change impacts on European viticulture. Food Energy Secur. 2012, 1, 94-110. [CrossRef]

9. Palliotti, A.; Tombesi, S.; Silvestroni, O.; Lanari, V.; Gatti, M.; Poni, S. Changes in vineyard establishment and canopy management urged by earlier climate-related grape ripening: A review. Sci. Hortic. 2014, 178, $43-54$. [CrossRef]

10. Van Leeuwen, C.; Destrac-Irvine, A. Modified grape composition under climate change conditions requires adaptations in the vineyard. OENO One 2017, 51, 147-154. [CrossRef]

11. Pavlousek, P. Evaluation of drought tolerance of new grapevine rootstock hybrids. J. Environ. Biol. 2011, 32, 543-549.

12. Marguerit, E.; Brendel, O.; Lebon, E.; van Leeuwen, C.; Ollat, N. Rootstock control of scion transpiration and its acclimation to water deficit are controlled by different genes. N. Phytol. 2012, 194, 416-429. [CrossRef] [PubMed]

13. Ollat, N.; Peccoux, A.; Papura, D.; Esmenjaud, D.; Marguerit, E.; Tandonnet, J.P.; Bordenave, L.; Cookson, S.J.; Barrieu, F.; Rossdeutsch, L.; et al. Rootstocks as a component of adaptation to environment. In Grapevine in a Changing Environment: A Molecular and Ecophysiological Perspective; Geros, H., Chaves, M., Medrano, H., Delrot, S., Eds.; Wiley-Blackwell: Oxford, UK, 2015; pp. 68-108. ISBN 978-1-118-73605-0.

14. Corso, M.; Bonghi, C. Grapevine rootstock effects on abiotic stress tolerance. Plant Sci. Today 2014, 1, $108-113$. [CrossRef]

15. Warschefsky, E.J.; Klein, L.L.; Frank, M.H.; Chitwood, D.H.; Londo, J.P.; von Wettberg, E.J.B.; Miller, A.J. Rootstocks: Diversity, domestication, and impacts on shoot phenotypes. Trends Plant Sci. 2016, 21, 418-437. [CrossRef] [PubMed]

16. Ollat, N.; Cookson, S.J.; Lauvergeat, V.; Marguerit, E.; Barrieu, F.; Gambetta, G.; Goutouly, J.P.; Tandonnet, J.P.; Vivin, P.; Delrot, S. Grapevines roots: The dark side. Acta Hortic. 2017, 1188, 213-226. [CrossRef]

17. Koundouras, S.; Hatzidimitriou, E.; Karamolegkou, M.; Dimopoulou, E.; Kallithraka, S.; Tsialtas, J.T.; Zioziou, E.; Nikolau, N.; Kotseridis, Y. Irrigation and rootstock effects on the phenolic concentration and aroma potential of Vitis vinifera L. cv. Cabernet Sauvignon grapes. J. Agric. Food Chem. 2009, 57, 7805-7813. [CrossRef]

18. Maré, C.; Aprile, A.; Roncaglia, E.; Tocci, E.; Corino, L.G.; De Bellis, G.; Cattivelli, L. Rootstock and soil induce transcriptome modulation of phenylpropanoid pathway in grape leaves. J. Plant Interact. 2013, 8, 334-349. [CrossRef]

19. Corso, M.; Vannozzi, A.; Maza, E.; Vitulo, N.; Meggio, F.; Pitacco, A.; Telatin, A.; D'Angelo, M.; Feltrin, E.; Negri, A.S.; et al. Comprehensive transcript profiling of two grapevine rootstock genotypes contrasting in drought susceptibility links the phenylpropanoid pathway to enhanced tolerance. J. Exp. Bot. 2015, 66, 5739-5752. [CrossRef]

20. Berdeja, M.; Nicolas, P.; Kappel, C.; Dai, Z.W.; Hilbert, G.; Peccoux, A.; Lafontaine, M.; Ollat, N.; Gomès, E.; Delrot, S. Water limitation and rootstock genotype interact to alter grape berry metabolism through transcriptome reprogramming. Hortic. Res. 2015, 2, 15012. [CrossRef]

21. Adams, D.O. Phenolics and Ripening in Grape Berries. Am. J. Enol. Vitic. 2006, 57, 249-256.

22. Teixeira, A.; Eiras-Dias, J.; Castellarin, S.; Geròs, H. Berry Phenolics of Grapevine under Challenging Environments. Int. J. Mol. Sci. 2013, 14, 18711-18739. [CrossRef]

23. Waterhouse, A.L. Wine phenolics. Ann. N. Y. Acad. Sci. 2002, 957, 21-36. [CrossRef] [PubMed]

24. Zombardo, A.; Crosatti, C.; Bagnaresi, P.; Bassolino, L.; Reshef, N.; Puccioni, S.; Faccioli, P.; Tafuri, A.; Delledonne, M.; Fait, A.; et al. Transcriptomic and biochemical investigations support the role of rootstock-scion interaction in grapevine berry quality. BMC Genom. 2020, in press.

25. Priori, S.; Barbetti, R.; L'Abate, G.; Bucelli, P.; Storchi, P.; Costantini, E.A.C. Natural terroir unit, Siena Province, Tuscany. J. Maps 2014, 10, 466-477. [CrossRef]

26. Nuzzo, V. Portinnesti. In La Nuova Viticoltura; Palliotti, A., Poni, S., Silvestroni, O., Eds.; Agricole: Bologna, Italy, 2015; pp. 52-71. ISBN 978-88-506-5453-6.

27. Zombardo, A.; Mica, E.; Puccioni, S.; Bassolino, L.; Perria, R.; Mattii, G.B.; Cattivelli, L.; Storchi, P. Influenza del portinnesto sul metabolismo secondario di uve Pinot nero. Infowine Internet J. Vitic. Enol. 2019, 10, 1-16. 
28. Winkler, A.J.; Cook, J.A.; Kliewer, W.M.; Lider, L.A. General Viticulture, 2nd ed.; University of California Press: Berkeley, CA, USA, 1974; p. 710. ISBN 9780520025912.

29. Lorenz, D.H.; Eichhorn, K.W.; Bleiholder, H.; Klose, R.; Meier, U.; Weber, E. Phenological growth stages of the grapevine (Vitis vinifera L. spp. vinifera)—Codes and descriptions according to the extended BBCH scale. Aust. J. Grape Wine Res. 1995, 1, 100-110. [CrossRef]

30. Coombe, B.G.; Mc Carthy, M.G. Dynamics of grape berry growth and physiology of ripening. Aust. J. Grape Wine Res. 2000, 6, 131-135. [CrossRef]

31. Puccioni, S.; Valentini, P.; Zombardo, A.; Leprini, M.; Perria, R.; Storchi, P.; Priori, S.; Costantini, E.A.C.; Salvi, L.; Cataldo, E.; et al. Interazione suolo-portinnesto in situazione di stress idrico in piante di vite allevate in vaso. Acta Italus Hortus 2016, 19, 95-96.

32. Naor, A. Midday stem water potential as a plant water stress indicator for irrigation scheduling in fruit trees. Acta Hortic. 2000, 537, 447-454. [CrossRef]

33. Scholander, P.F.; Bradstreet, E.D.; Hemmingsen, E.A.; Hammel, H.T. Sap pressure in vascular plants. Science 1965, 148, 339-346. [CrossRef]

34. Kitajima, M.; Butler, W.L. Quenching of chlorophyll fluorescence and primary photochemistry in chloroplasts by dibromothymoquinone. Biochim. Biophys. Acta Bioenerg. 1975, 376, 105-115. [CrossRef]

35. International Organisation of Vine and Wine. Compendium of International Methods of Analysis of Wines and Musts. Available online: http:/www.oiv.int/en/technical-standards-and-documents/methods-of-analysis/ compendium-of-international-methods-of-analysis-of-wines-and-musts-2-vol (accessed on 26 March 2020).

36. Di Stefano, R.; Cravero, M.C. Metodi per lo studio dei polifenoli dell'uva. Riv. Viticolt. Enol. 1991, 2, $37-45$.

37. Singleton, V.L.; Orthofer, R.; Lamuela-Raventòs, R.M. Analysis of total phenols and other oxidation substrates and antioxidants by means of Folin-Ciocalteu reagent. Method Enzymol. 1999, 299, 152-178. [CrossRef]

38. Gómez-Alonso, S.; Garcia-Romero, E.; Hermosìn-Gutiérrez, I. HPLC analysis of diverse grape and wine phenolics using direct injection and multidetection by DAD and fluorescence. J. Food Compos. Anal. 2007, 20, 618-626. [CrossRef]

39. Varkonyi-Gasic, E.; Wu, R.; Wood, M.; Walton, E.F.; Hellens, R.P. Protocol: A highly sensitive RT-PCR method for detection and quantification of microRNAs. Plant Methods 2007, 3, 12. [CrossRef] [PubMed]

40. Livak, K.J.; Schmittgen, T.D. Analysis of relative gene expression data using real-time quantitative PCR and the $2^{-\Delta \Delta \mathrm{Ct}}$ method. Methods 2001, 25, 402-408. [CrossRef]

41. De Lorenzis, G.; Squadrito, M.; Rossoni, M.; Di Lorenzo, G.S.; Brancadoro, L.; Scienza, A. Study of intra-varietal diversity in biotypes of Aglianico and Muscat of Alexandria (Vitis vinifera L.) cultivars. Aust. J. Grape Wine Res. 2016, 23, 132-142. [CrossRef]

42. Poni, S.; Intrieri, C. Grapevine photosynthesis: Effects linked to light radiation and leaf age. Adv. Hort. Sci. 2001, 15, 5-15.

43. Schultz, H. Climate change and viticulture: A European perspective on climatology, carbon dioxide and UV-B effects. Aust. J. Grape Wine Res. 2000, 6, 2-12. [CrossRef]

44. Ferrini, F.; Mattii, G.B.; Nicese, F.P. Effect of Temperature on Key Physiological Responses of Grapevine Leaf. Am. J. Enol. Vitic. 1995, 46, 375-379.

45. Ollat, N.; Diakou-Verdin, P.; Carde, J.P.; Barrieu, F.; Gaudillère, J.P.; Moing, A. Grape berry development: A review. OENO One 2002, 36, 109-131. [CrossRef]

46. Poni, S.; Lakso, A.N.; Turner, J.R.; Melious, R.E. The effects of pre- and post-veraison water stress on growth and physiology of potted Pinot noir grapevines at varying crop levels. Vitis 1993, 32, 207-214.

47. Poorter, H.; Bühler, J.; van Dusschoten, D.; Climent, J.; Postma, J.A. Pot size matters: A meta-analysis of the effects of rooting volume on plant growth. Funct. Plant Biol. 2012, 39, 839-850. [CrossRef]

48. Herrera, J.C.; Savi, T.; Rosner, S.; Forneck, A. The Size matters: Drought Stress Experiments with Potted Vines. In Proceedings of the 4th Xylem International Meeting, Padua, Italy, 25-27 September 2019; p. 64.

49. Mattivi, F.; Guzzon, R.; Vrhovsek, U.; Stefanini, M.; Velasco, R. Metabolite profiling of Grape: Flavonols and Anthocyanins. J. Agric. Food Chem. 2006, 54, 7692-7702. [CrossRef] [PubMed]

50. Boss, P.K.; Davies, C.; Robinson, S.P. Analysis of the expression of anthocyanin pathway genes in developing Vitis vinifera L. cv. Shiraz grape berries and the implications for pathway regulation. Plant Physiol. 1996, 111, 1059-1066. [CrossRef] [PubMed] 
51. Falginella, L.; Castellarin, S.; Testolin, R.; Gambetta, G.; Morgante, M.; Di Gaspero, G. Expansion and subfunctionalisation of flavonoid 3',5'-hydroxylases in the grapevine lineage. BMC Genom. 2010, 11, 562. [CrossRef] [PubMed]

52. Bogs, J.; Ebadi, A.; Mc David, D.; Robinson, S.P. Identification of the Flavonoid Hydroxylases from Grapevine and Their Regulation during Fruit Development. Plant Physiol. 2006, 140, 279-291. [CrossRef]

53. Downey, M.O.; Harvey, J.S.; Robinson, S.P. Synthesis of flavonols and expression of flavonol synthase genes in developing grape berries of Shiraz and Chardonnay (Vitis vinifera L.). Aust. J. Grape Wine Res. 2003, 9, 110-121. [CrossRef]

54. Cavallini, E.; Matus, J.T.; Finezzo, L.; Zenoni, S.; Loyola, R.; Guzzo, F.; Schlechter, R.; Ageorges, A.; Arce-Johnson, P.; Tornielli, G.B. The phenylpropanoid pathway is controlled at different branches by a set of R2R3-MYBC2 repressors in grapevine. Plant Physiol. 2015, 167, 1448-1470. [CrossRef]

55. Suzuki, M.; Nakabayashi, R.; Ogata, Y.; Sakurai, N.; Tokimatsu, T.; Goto, S.; Jasinski, M.; Martinoia, E.; Otagaki, S.; Matsumoto, S.; et al. Multiomics in Grape Berry Skin Revealed Specific induction of the Stilbene Synthetic Pathway by Ultraviolet-C irradiation. Plant Physiol. 2015, 168, 47-59. [CrossRef]

56. Palumbo, M.C.; Zenoni, S.; Fasoli, M.; Massonnet, M.; Farina, L.; Castiglione, F.; Pezzotti, M.; Paci, P. Integrated Network Analysis Identifies Fight-Club Nodes as a Class of Hubs Encompassing Key Putative Switch Genes That Induce Major Transcriptome Reprogramming during Grapevine development. Plant Cell 2014, 26, 4617-4635. [CrossRef]

57. Kawashima, C.G.; Yoshimoto, N.; Maruyama-Nakashita, A.; Tsuchiya, Y.N.; Saito, K.; Takahashi, H.; Dalmay, T. Sulphur starvation induces the expression of microRNA-395 and one of its target genes but in different cell types. Plant J. 2009, 57, 313-321. [CrossRef] [PubMed]

58. Tavares, S.; Vesentini, D.; Fernandes, J.C.; Ferreira, R.B.; Laureano, O.; Ricardo-Da-Silva, J.M.; Amancio, A. Vitis vinifera secondary metabolism as affected by sulfate depletion: Diagnosis through phenylpropanoid pathway genes and metabolites. Plant Physiol. Biochem. 2013, 66, 118-126. [CrossRef] [PubMed]

59. Belli Kulhan, J.; Paim Pinto, D.L.; Bertolini, E.; Fasoli, M.; Zenoni, S.; Tornielli, G.B.; Pezzotti, M.; Meyers, B.C.; Farina, L.; Pé, M.E.; et al. miRVine: A micro RNA expression atlas of grapevine based on small RNA sequencing. BMC Genom. 2015, 16, 393. [CrossRef] [PubMed]

60. Ojeda, H.; Deloire, A.; Carbonneau, A. Influence of water deficits on grape berry growth. Vitis 2001, 40, 141-145.

61. Keller, M. The Science of Grapevines: Anatomy and Physiology, 1st ed.; Elsevier Academic Press: Burlington, MA, USA, 2010; p. 400. ISBN 978-0123748812.

62. Jaillon, O.; Aury, J.M.; Noel, B.; Policriti, A.; Clepet, C.; Casagrande, A.; Choisne, N.; Aubourg, S.; Vitulo, N.; Jubin, C.; et al. The grapevine genome sequence suggests ancestral hexaploidization in major angiosperm phyla. Nature 2007, 449, 463-467. [CrossRef]

63. Velasco, R.; Zharkikh, A.; Troggio, M.; Cartwright, D.A.; Cestaro, A.; Pruss, D.; Pindo, M.; FitzGerald, L.M.; Vezzulli, S.; Reid, J.; et al. A high-quality draft consensus sequence of the genome of a heterozygous grapevine variety. PLoS ONE 2007, 12, e1326. [CrossRef]

64. Lovisolo, C.; Perrone, I.; Carra, A.; Ferrandino, A.; Flexas, J.; Medrano, H.; Schubert, A. Drought-induced changes in development and function of grapevine (Vitis spp.) organs and in their hydraulic and non-hydraulic interactions at the whole-plant level: A physiological and molecular update. Funct. Plant Biol. 2010, 37,98-116. [CrossRef]

65. Palliotti, A.; Tombesi, S.; Frioni, T.; Famiani, F.; Silvestroni, O.; Zamboni, M.; Poni, S. Morpho-structural and physiological response of container-grown Sangiovese and Montepulciano cvv. (Vitis vinifera) to re-watering after a pre-veraison limiting water deficit. Funct. Plant Biol. 2014, 41, 634-647. [CrossRef]

66. Castellarin, S.D.; Bucchetti, B.; Falginella, L.; Peterlunger, E. Influenza del deficit idrico sulla qualità delle uve: Aspetti fisiologici e molecolari. Acta Italus Hortus 2011, 14, 63-79.

67. Palliotti, A.; Poni, S. Grapevine under light and heat stresses. In Grapevine in a Changing Environment: A Molecular and Ecophysiological Perspective; Gerós, H., Chaves, M.M., Medrano Gil, H., Delrot, S., Eds.; Wiley Blackwell: Oxford, UK, 2015; pp. 148-178. [CrossRef]

68. Pulko, B.; Vršič, S.; Valdhuber, J. Influence of Various Rootstocks on the Yield and Grape Composition of Sauvignon Blanc. Czech J. Food Sci. 2012, 30, 467-473. [CrossRef] 
69. Bauerle, T.L.; Smart, D.R.; Bauerle, W.L.; Stockert, C.; Eissenstat, D.M. Root foraging in response to heterogeneous soil moisture in two grapevines that differ in potential growth rate. N. Phytol. 2008, 179, 857-866. [CrossRef] [PubMed]

70. Ferroni, G.; Scalabrelli, G. Effect of rootstocks on vegetative activity and yield in grapevine. Acta Hortic. 1995, 388, 37-42. [CrossRef]

71. Keller, M.; Mills, L.J.; Harbertson, J.F. Rootstock Effects on Deficit-Irrigated Winegrapes in a Dry Climate: Vigor, Yield Formation, and Fruit Ripening. Am. J. Enol. Vitic. 2012, 63, 29-39. [CrossRef]

72. Girona, J.; Mata, M.; Del Campo, J.; Arbonés, A.; Bartra, E.; Marsal, J. The use of midday leaf water potential for scheduling deficit irrigation in vineyards. Irrig. Sci. 2006, 24, 115-127. [CrossRef]

73. Guidoni, S.; Ferrandino, A.; Novello, V. Effects of seasonal and agronomical practices on skin anthocyanin profile of Nebbiolo grapes. Am. J. Enol. Vitic. 2008, 1, 22-29.

74. Castellarin, S.D.; Di Gaspero, G.; Marconi, R.; Nonis, A.; Peterlunger, E.; Paillard, S.; Adam-Blondon, A.F.; Testolin, R. Colour variation in red grapevines (Vitis vinifera L.): Genomic organisation, expression of flavonoid $3^{\prime}$-hydroxylase, flavonoid 3',5'-hydroxylase genes and related metabolite profiling of red cyanidin-/blue delphinidin-based anthocyanins in berry skin. BMC Genom. 2006, 7, 12. [CrossRef]

75. Castellarin, S.D.; Matthews, M.A.; Di Gaspero, G.; Gambetta, G.A. Water deficits accelerate ripening and induce changes in gene expression regulating flavonoid biosynthesis in grape berries. Planta 2007, 227, 101-112. [CrossRef]

76. De Freitas, V.A.P.; Fernandes, A.; Oliveira, J.; Teixeira, N.; Mateus, N. A review of the current knowledge of red wine colour. OENO One 2017, 51, 1-21. [CrossRef]

77. Mijowska, K.; Ochmian, I.; Oszmiański, J. Rootstock effects on polyphenol content in grapes of 'Regent' cultivated under cool climate condition. J. Appl. Bot. Food Qual. 2017, 90, 159-164. [CrossRef]

78. Jeandet, P.; Delaunois, B.; Conreux, A.; Donnez, D.; Nuzzo, V.; Cordelier, S.; Clement, C.; Courot, E. Biosynthesis, metabolism, molecular engineering, and biological functions of stilbene phytoalexins in plants. Bio Fact. 2010, 36, 331-341. [CrossRef]

79. Pastor, R.F.; Restani, P.; Di Lorenzo, C.; Orgiu, F.; Teissedre, P.L.; Stockley, C.; Ruf, J.C.; Quini, C.I.; Garcia Tejedor, N.; Gargantini, R.; et al. Resveratrol, human health and winemaking perspectives. Crit. Rev. Food Sci. Nutr. 2019, 59, 1237-1255. [CrossRef] [PubMed]

80. Wang, N.; Zheng, Y.; Xin, H.; Fang, L.; Li, S. Comprehensive analysis of NAC domain transcription factor gene family in Vitis vinifera. Plant Cell Rep. 2013, 32, 61-75. [CrossRef] [PubMed]

81. Nakashima, K.; Tran, L.S.; Van Nguyen, D.; Fujita, M.; Maruyama, K.; Todaka, D.; Ito, Y.; Hayashi, N.; Shinozaki, K.; Yamaguchi-Shinozaki, K. Functional analysis of a NAC-type transcription factor OsNAC6 involved in abiotic and biotic stress-responsive gene expression in rice. Plant J. 2007, 51, 617-630. [CrossRef] [PubMed]

82. Tran, L.S.; Quach, T.N.; Guttikonda, S.K.; Aldrich, D.L.; Kumar, R.; Neelakandan, A.; Valliyodan, B.; Nguyen, H.T. Molecular characterization of stress-inducible GmNAC genes in soybean. Mol. Genet. Genom. 2009, 281, 647-664. [CrossRef] [PubMed]

83. Chuck, G.; Candela, H.; Hake, S. Big impact by small RNAs in plant development. Curr. Opin. Plant Biol. 2009, 12, 81-86. [CrossRef]

84. Mica, E.; Piccolo, V.; Delledonne, M.; Ferrarini, A.; Pezzotti, M.; Casati, C.; Del Fabbro, C.; Valle, G.; Policriti, A.; Morgante, M.; et al. Correction: High throughput approaches reveal splicing of primary microRNA transcripts and tissue specific expression of mature microRNAs in Vitis vinifera. BMC Genom. 2010, 11, 109. [CrossRef]

85. Solofoharivelo, M.C.; Van der Walt, A.P.; Stephan, D.; Burger, J.T.; Murray, S.L. MicroRNAs in fruit trees: Discovery, diversity and future research directions. Plant Biol. 2014, 16, 856-865. [CrossRef]

86. Pagliarani, C.; Vitali, M.; Ferrero, M.; Vitulo, N.; Incarbone, M.; Lovisolo, C.; Valle, G.; Schubert, A. The accumulation of microRNAs differentially modulated by drought is affected by grafting in grapevine. Plant Physiol. 2017, 173, 2180-2195. [CrossRef]

87. Yang, Y.; Mao, L.; Jittayasothorn, Y.; Kang, Y.; Jiao, C.; Fei, Z.; Zhong, G.Y. Messenger RNA exchange between scions and rootstocks in grafted grapevines. BMC Plant Biol. 2015, 15, 251. [CrossRef]

88. Zhou, L.; Liu, Y.; Liu, Z.; Kong, D.; Duan, M.; Luo, L. Genome-wide identification and analysis of drought-responsive microRNAs in Oryza sativa. J. Exp. Bot. 2010, 61, 4157-4168. [CrossRef] 
89. Paim Pinto, D.L.; Brancadoro, L.; Dal Santo, S.; De Lorenzis, G.; Pezzotti, M.; Meyers, B.C.; Pé, M.E.; Mica, E. The influence of genotype and environment on small RNA profiles in grapevine berry. Front. Plant Sci. 2016, 7, 1459. [CrossRef] [PubMed]

90. Han, J.; Fang, J.; Wang, C.; Yin, Y.; Sun, X.; Leng, X.; Song, C. Grapevine microRNAs responsive to exogenous gibberellin. BMC Genom. 2014, 15, 111. [CrossRef] [PubMed] 